Universidad de Lima

Escuela de Posgrado

Maestría en Tributación y Política Fiscal

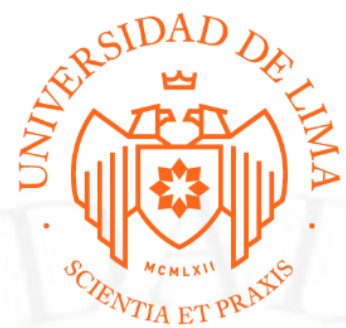

\title{
EL NUEVO RUS: HERRAMIENTA PARA AMPLIAR LA BASE TRIBUTARIA Y REDUCIR LA INFORMALIDAD
}

Trabajo de investigación para optar el Grado Académico de Maestro en Tributación y Política Fiscal

\section{Denisse Isabel Castillo Sabogal}

Código 20162703

\author{
Asesor \\ Mario Madau Martínez \\ Lima - Perú \\ Julio de 2019
}




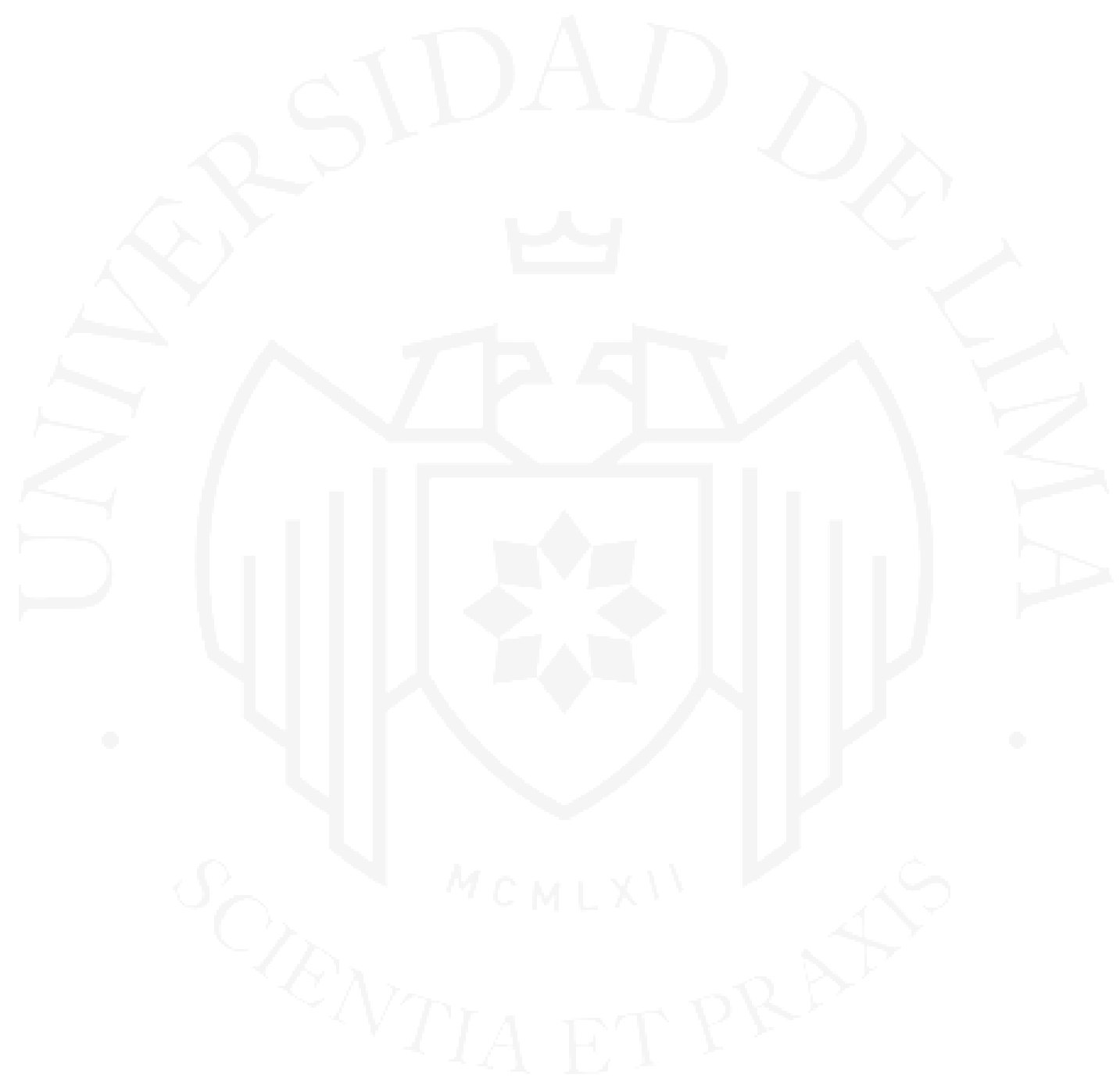




\section{EL NUEVO RUS: HERRAMIENTA PARA AMPLIAR LA BASE TRIBUTARIA Y REDUCIR LA INFORMALIDAD}

\section{THE NEW RUS: TOOL TO EXPAND THE TAXPAYERS BASE AND REDUCE INFORMALITY}




\section{TABLA DE CONTENIDO}

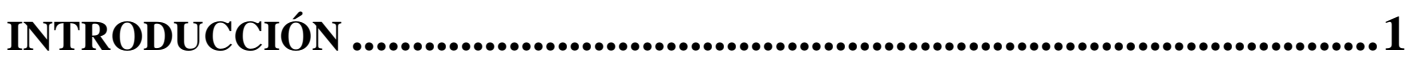

CAPÍTULO I: ASPECTOS GENERALES ..........................................3

1.1 Nociones generales del Sistema Tributario Peruano …................................. 3

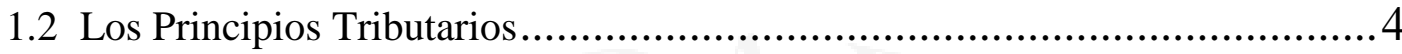

1.2.1 El Principio de Reserva de Ley y Principio de Legalidad .....................5

1.2.2 El Principio de Igualdad y los Principios Tributarios de Capacidad

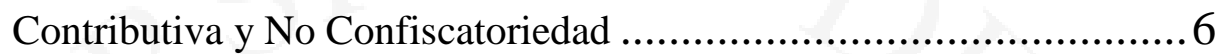

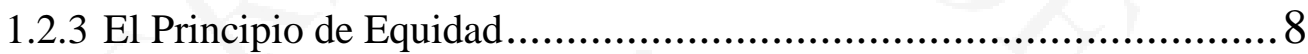

1.2.4 El deber de contribuir con el gasto público ........................................

1.2.5 El Principio de Economía en la Recaudación .....................................10

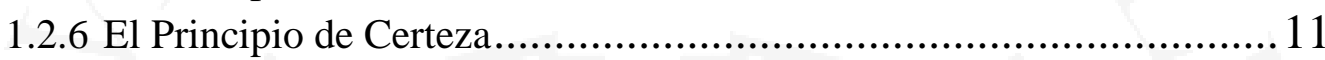

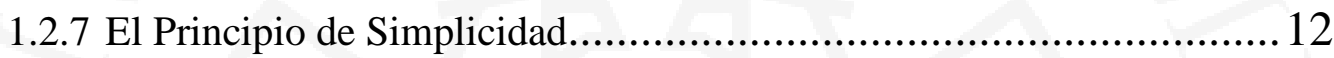

1.2.8 El Principio de respeto de los derechos fundamentales de la persona ...13

1.3 Nuevo Régimen Único Simplificado - Nuevo RUS ..................................... 14

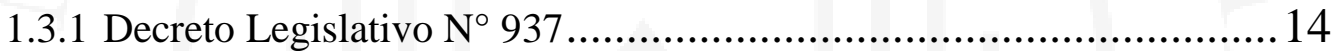

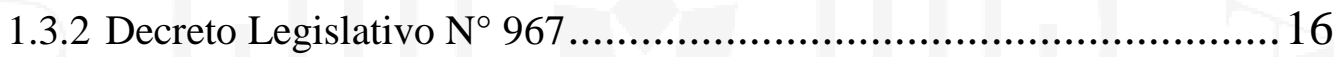

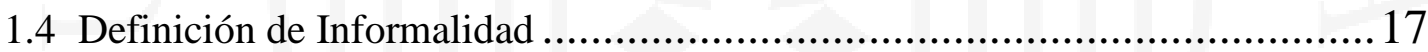

1.5 Estimación Directa y Estimación Objetiva del impuesto a la renta...................20

CAPÍTULO II: LA REFORMA TRIBUTARIA DEL 2016 ..........................22

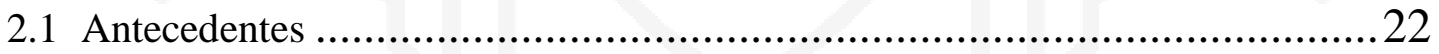

2.2 Exposición de Motivos del Poder Ejecutivo .................................................24

2.3 Decreto Legislativo $\mathrm{N}^{\circ}$ 1258: Deducción Adicional del Impuesto a la Renta para

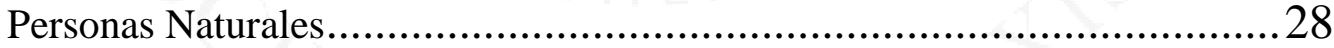

2.4 Decreto Legislativo $N^{\circ}$ 1269: Crea el Régimen MYPE Tributario ……............31

2.4.1 Las MYPE en el Perú.................................................................. 31

2.4.2 Características del régimen tributario creado .....................................32

2.4.3 Factores no considerados en la creación de Régimen MYPE

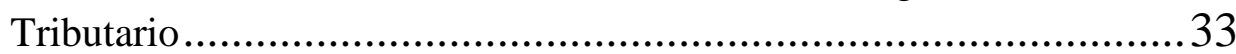

2.5 Decreto Legislativo $\mathrm{N}^{\circ}$ 1270: Modifica el Régimen Único Simplificado .........35

2.6 Efectos en la Recaudación de La Reforma Tributaria .....................................37

2.6.1 Caída en la Recaudación del Impuesto a la Renta Empresarial..............37

2.6.2 Variación de la Base Tributaria de contribuyentes que generan Renta

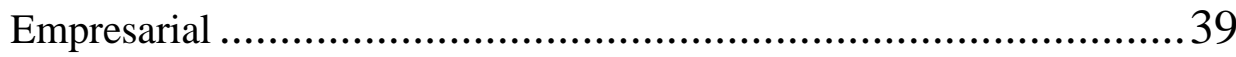


2.7 Conclusiones preliminares

CAPÍTULO III: REGIMENES SIMPLIFICADOS EN LA LEGISLACIÓN COMPARADA ............................................................................................44

3.1 La Situación de América Latina ........................................................... 44

3.2 Argentina: Régimen Simplificado para Pequeños Contribuyentes 47

3.3 El Régimen de Estimación Objetiva sobre el Impuesto a la Renta de las Personas Físicas (IRPF) Español ...............................................................53

3.4 Simplificación Tributaria Italiana...................................................56

3.4.1 Régimen "forfettario" o de tarifa plana ...................................55

3.4.2 Régimen para las actividades marginales ("per le attività marginali" o "forfettone") ...................................................................59

3.4.3 Régimen para las nuevas iniciativas empresariales y trabajadores

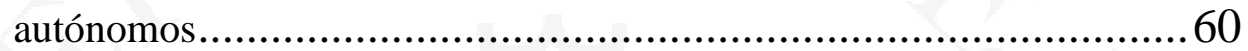

3.4.4 Estudios de Sector ............................................................62

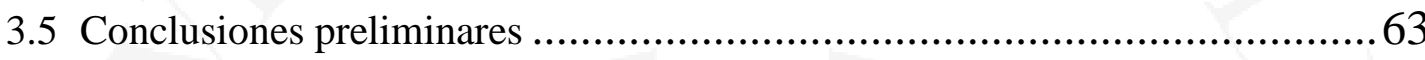

CAPÍTULO IV: ASPECTOS A CONSIDERAR EN EL PERFECCIONAMIENTO DEL NUEVO REGIMEN ÚNICO SIMPLIFICADO EN EL PERU .............65

4.1 La Administración Tributaria - SUNAT ...............................................6. 65

4.2 Análisis del costo-beneficio de perfeccionar el Nuevo RUS .......................66

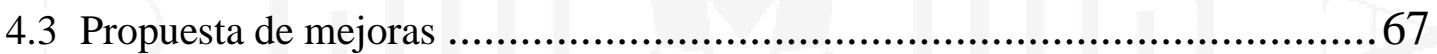

CONCLUSIONES ....................................................................70

RECOMENDACIONES ................................................................................... 72

REFERENCIAS ...................................................................................74

BIBLIOGRAFÍA ................................................................................................80 


\section{ÍNDICE DE TABLAS}

Tabla 1.1 Tablas de categorías del Nuevo RUS creado con Decreto Legislativo $N^{\circ} 937$

Tabla 1.2 Tabla de categorías de Nuevo RUS vigentes hasta el 31 de diciembre 2016. 17 Tabla 2.1 Gastos adicionales deducibles del Impuesto a la Renta para Personas Naturales 28

Tabla 2.2 Acreditación - Sustentación de Gastos en Restaurantes y Hoteles para

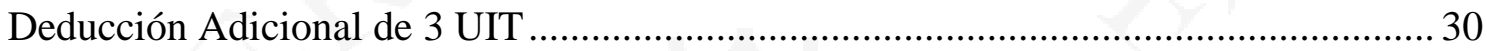

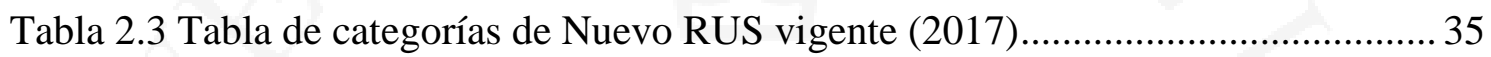

Tabla 2.4 Tabla de categorías de RUS - Decreto Legislativo $\mathrm{N}^{\circ} 777$........................... 36

Tabla 2.5 Ingresos Tributarios del Gobierno Central - En millones de soles y variación

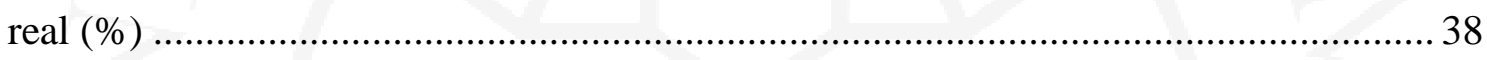

Tabla 2.6 Recaudación de las Rentas Empresariales 2017 (Proyectado versus Ejecutado) 38

Tabla 2.7 Contribuyentes Inscritos según Régimen Tributario, Variación 2016 - 2017 (En miles) 40

Tabla 2.8 Contribuyentes Inscritos según Régimen Tributario, Variación 2015 - 2016 (En miles)

Tabla 2.9 Cuadro Comparativo de los Regímenes Tributarios vigentes después de la Reforma Tributaria 43

Tabla 3.1 Ingreso bruto promedio mensual por categoría del Régimen Simplificado para Pequeños Contribuyentes - Monotributo Argentino expresado en cantidad de sueldos mínimos argentinos $(11,300$ ARS $)$

Tabla 3.2 Ingreso bruto promedio mensual por categoría del Régimen Simplificado para Pequeños Contribuyentes - Monotributo Argentino expresado en cantidad de sueldos mínimos peruanos $(\mathrm{S} / 930)$ .52 


\section{RESUMEN}

Esta investigación determina la necesidad de regímenes simplificados en el Sistema Tributario Peruano a fin de reducir la informalidad con la ampliación de la base tributaria. Se hace hincapié en la los beneficios de la formalidad, no solo para el contribuyente si no para el Estado. Analizamos el Nuevo Régimen Único Simplificado (Nuevo RUS), régimen tributario creado con el fin de reducir la informalidad y ampliar la base tributaria, dirigido a contribuyentes que le venden o brindan servicios exclusivamente a consumidores finales. Asimismo, resultado de la revisión de legislación comparada, buenas prácticas de otros países en regímenes simplificados, enumeramos las oportunidades de mejora del Nuevo RUS, acompañado de medidas en el Estado (Cultura Tributaria) y la Administración Tributaria - SUNAT (mejora de plataformas informáticas).

Palabras clave: Nuevo RUS, informalidad, base tributaria, régimen simplificado 


\begin{abstract}
This investigation determines the need for simplified regimes in the Peruvian tax system to reduce informality with the expansion of the taxpayer base. The benefits of formality are emphasized, not only for the taxpayer but also for the State. We analyze the New Simplified Single Regime (New RUS), a tax regime created to reduce informality and expand the taxpayer base, aimed at taxpayers who sell or provide services exclusively to end consumers. Likewise, as a result of the revision of the comparative legislation, the good practices of other countries in simplified tax regimes, we enumerate the opportunities for improvement of the New RUS, accompanied by measures in the State (Fiscal Culture) and the Tax Administration - SUNAT (improvement of computer platforms).
\end{abstract}

Keywords: New RUS, informality, taxpayer base, simplified regime 


\section{INTRODUCCIÓN}

En el Perú, la informalidad es un problema endémico que afecta al desarrollo del país, a la recaudación tributaria y, por ende, a la capacidad del estado de cubrir el gasto público. En ese sentido, las Políticas Tributarias del país buscan establecer un Sistema Tributario atractivo para los "contribuyentes", que estando en la informalidad quieran ser formales o que siendo formales no se vean tentados a dejar dicha formalidad.

De este modo, el presente trabajo pretende abordar este problema analizando en primer lugar como funciona el Sistema Tributario peruano y los principios tributarios que lo rigen. Asimismo, se comentará la involución del Nuevo Régimen Único Simplificado (Nuevo RUS), régimen simplificado creado con el fin de reducir la informalidad y ampliar la base tributaria, dirigido a contribuyentes que le venden o brindan servicios exclusivamente a consumidores finales. Definiremos qué es informalidad y los factores exógenos que llevan a los ciudadanos a ella. Enumeraremos los beneficios de la formalidad, no solo para el contribuyente si no para el Estado, ya que la formalidad de estos contribuyentes implica, por ejemplo, una reducción del desempleo (con el autoempleo), por lo que el Estado debe ser el principal interesado de facilitar este proceso. Que los regímenes basados en Estimación Objetiva son la solución a la complejidad que implica la determinación de impuestos bajo regímenes de Estimación Directa.

En segundo lugar, analizaremos la Reforma Tributaria del 2016 (vigente a partir del 2017), haciendo hincapié en los decretos legislativos que tenían como objeto la ampliación de la base tributaria o la reducción de la informalidad: Decretos Legislativos $\mathrm{N}^{\circ} 1258,1269$ y 1270, exposición de motivos y principales características. De igual modo, el efecto negativo de estas medidas en la recaudación tributaria del Impuesto a la Renta Empresarial (Tercera Categoría) y su nulo impacto en la base tributaria.

Es importante precisar que, aunque durante el desarrollo del segundo capítulo criticamos el Régimen MYPE, nuestras críticas no son al régimen en sí, sino a que sus efectos en la formalidad han sido contrarios a lo que la reforma tributaria buscaba. 
Y en tercer lugar, conscientes de que la informalidad no es una preocupación exclusiva del Perú, analizaremos por América Latina, en términos generales, los motivos que la generan y el hecho de que una de las medidas más comunes para reducir esta situación es la implementación de regímenes simplificados para pequeños contribuyentes. Asimismo, analizaremos los regímenes simplificados de Argentina, España e Italia, regímenes simplificados que tienen unificado el pago de impuesto a la renta y el impuesto al valor agregado en un único pago, al igual que el Nuevo RUS. Resultado del análisis de esta legislación comparada, buscaremos identificar oportunidades de mejora de nuestro régimen (perfeccionamiento).

Por último, en base a lo analizado, listaremos algunas características u oportunidades de mejora que consideramos se deben incorporar en el Nuevo RUS para mejorar los resultados en su objetivo de reducir con la informalidad y ampliación de la base tributaria. Sin dejar de lado, que desde todos los niveles del Estado se debe trabajar para cambiar la percepción de los ciudadanos en relación a que tan importante es pagar impuestos y la labor que cumple la Administración Tributaria en dicho proceso. 


\section{CAPÍTULO I: ASPECTOS GENERALES}

\subsection{Nociones generales del Sistema Tributario Peruano}

El Sistema Tributario peruano se puede definir como el conjunto de normas, principios e instituciones que regulan las relaciones procedentes de la aplicación de tributos, y otros que garanticen el flujo de este al Estado. Se rige bajo el Decreto Legislativo $N^{\circ} 771$ - Ley Marco del Sistema Tributario Nacional (enero de 1994). El Estado es el poder político organizado en tres niveles de gobierno: nacional, regional y local, cuyos costos operativos deben ser financiados con la recaudación de tributos que les toque administrar. No obstante, en la realidad, el financiamiento de los gobiernos regional y local está compuesto en gran porcentaje de la recaudación directa o indirecta que ejecuta del gobierno nacional: los impuestos del Gobierno Central.

Son factores determinantes del sistema Tributario:

- $\quad$ La Política Tributaria, diseñada por el Poder ejecutivo a través del Ministerio de Economía y Finanzas (MEF). Se espera que esta asegure la sostenibilidad de las Finanzas Públicas a largo plazo.

- Las Normas Tributarias, establecidas por el Poder Legislativo a través del Congreso de la Republica, que se espera se alineen a las Políticas Tributarias establecidas. Las Normas Tributarias propuestas por el Poder Legislativo deben ser revisadas y contar con el visto bueno del Poder Ejecutivo en teoría, en la realidad el Poder Legislativo puede promulgarlas a pesar de las observaciones que esta pueda tener. El Poder Ejecutivo puede legislar en materia tributaria cuando el Poder Legislativo le delegue esta facultad, otra vez en teoría, en la realidad el Poder Legislativo limita la facultad delegada y revisa lo promulgado por el Poder Ejecutivo y puede derogar lo que a su criterio exceda las facultades otorgadas. Vale mencionar que las principales reformas tributarias dadas en el país se han dado por paquetes tributarios emitidos por el Poder Ejecutivo. Siendo, en nuestra opinión, un factor 
determinante en la calidad de la reforma tributaria la relación que se da dentro del Congreso de la República entre la "bancada de gobierno" y la "bancada de oposición”.

- La Administración Tributaria, órgano del estado, por nivel de gobierno, responsable de aplicar la norma tributaria, pero principalmente de recaudar el tributo. En el Gobierno Nacional, esta obligación recae en la Superintendencia Nacional de Aduanas y de Administración Tributaria, en adelante SUNAT.

Resultaría una tarea innecesaria, para el objetivo de este trabajo de investigación, enumerar todas las normas tributarias de nuestro sistema tributario, es especial hacerle seguimiento al sin fin de sus modificatorias, considerando que "confuso" es uno de los adjetivos que más se usa para describirlo. Pero son dos (2) las que le dan el marco legal necesario para su validez y desarrollo, como son:

La constitución Política del Perú, marco normativo de la legislación del país en sus diversas ramas. Establece los límites y los principios en los que se rige la norma tributaria. Es en ese sentido que es el Tribunal Constitucional el último órgano jurisdiccional en pronunciarse sobre la validez de la vigencia de las normas tributarias o la interpretación de su aplicación.

- Código Tributario, con el que se regulan las relaciones fisco - contribuyente / Administrador - Administrado, con el fin de garantizar un correcto funcionamiento del sistema tributario. Es la Ley del Procedimiento Administrativo General la norma que llena aquellos vacíos procedimentales que podría no haber considerado el código.

En la relación tributaria se identifican dos (2) sujetos: el activo (la administración) y el pasivo (el administrado), pudiendo ser este último:

- $\quad$ Persona Natural o Física, ejerce sus derechos y responde a sus obligaciones a título personal.

- Persona Jurídica o Moral, entidad (constituida) conformada por una, dos o más personas, que ejerce derechos y responde a obligaciones a título de esta.

\subsection{Los Principios Tributarios}


La Constitución Política del Perú en su artículo $74^{\circ}$ establece los principios que limitan al Estado al ejercer la Potestad Tributaria (crear o suprimir impuestos) y garantías de que no se ejerza con arbitrariedad.

Explícitamente establece los principios de Reserva de la ley, no confiscatoriedad, los de igualdad y respeto de los derechos fundamentales de la persona, pero sin definirlos o delimitarlos. El Tribunal Constitucional, como máximo intérprete de la Constitución, es quien le ha dado contenido y alcance a dichos principios, garantizando que se cumplan los principios de supremacía constitucional y el principio de fuerza normativa de que la Constitución incorporo en el articulo $51^{\circ}$. Siendo que de dichas interpretaciones ha listado otros principios tributarios adicionales (implícitos): los de Legalidad, Capacidad Contributiva, economía en la recaudación, deber de contribuir con los gastos públicos, equidad, publicidad, justicia tributaria, seguridad jurídica, certeza y simplicidad, entre otros.

\subsubsection{El Principio de Reserva de Ley y Principio de Legalidad}

A criterio de Tribuna Constitucional (2005):

"no existe identidad entre el principio de legalidad y el de reserva de ley. Mientras que el principio de legalidad, en sentido general, se entiende como la subordinación de todos los poderes públicos a leyes generales y abstractas que disciplinan su forma de ejercicio y cuya observancia se halla sometida a un control de legitimidad por jueces independientes; el principio de reserva de ley, por el contrario, implica una determinación constitucional que impone la regulación, sólo por ley, de ciertas materias" (STC 0042-2004$\mathrm{AI} / \mathrm{TC})$.

El principio de Reserva de Ley limita la creación, modificación, derogación, exoneración - entre otros - a lo establecido en la propia Constitución (1993):

"exclusivamente por ley o decreto legislativo en caso de delegación de facultades [negritas añadidas], salvo los aranceles y tasas, los cuales se regulan mediante decreto supremo. Los Gobiernos Regionales y los Gobiernos Locales pueden crear, modificar y suprimir contribuciones y tasas, o exonerar de éstas, 
dentro de su jurisdicción, y con los límites que señala la ley (...) Las leyes de presupuesto y los decretos de urgencia no pueden contener normas sobre materia tributaria" (artículo $74^{\circ}$ ).

Al respecto, el Tribunal Constitucional (2014) precisó que esto significaba que:

"todos los elementos esenciales del tributo (hecho generador, base imponible, sujetos y alícuota) sean creados mediante ley. En tal sentido, la remisión de elementos esenciales del tributo a normas reglamentarias únicamente será constitucionalmente admisible cuando dicha delegación establezca parámetros claramente definidos de antemano y exista una racionalidad que así lo justifique" (STC 01902-2013-AA/TC).

Por otro lado, el principio de Legalidad significa que la potestad tributaria del Estado "está sometida, en primer lugar, a la Constitución y, en segundo lugar, a la ley" (STC 0042-2004-AI/TC), es decir, que ninguna norma tributaria puede ir en contra a lo establecido en la constitución, lo que ha llevado a múltiples derogatorias resultado de la interpretación y pronunciamiento del Tribunal Constitucional.

El principio de Reserva de Ley es importante para esta investigación, como veremos en capítulos posteriores, el Poder Ejecutivo tiene la oportunidad de legislar en materia tributaria y alinearlo a sus políticas tributarias, pero solo con la delegación del Poder Legislativo y con los límites que esta establezca. Juega un papel coyuntural importante la relación entre los que lideran estos dos (2) poderes la efectividad de una reforma tributaria.

\subsubsection{El Principio de Igualdad y los Principios Tributarios de Capacidad Contributiva y No Confiscatoriedad}

El Tribunal Constitucional (2003) establece que los principios tributarios de Capacidad Contributiva y No Confiscatoriedad son implícitos al Principio de Igualdad: 
“4. Uno de los principios constitucionales a los cuales está sujeta la potestad tributaria del Estado es el de no confiscatoriedad de los tributos. Este principio informa y limita el ejercicio de la potestad tributaria estatal y, como tal, constituye un mecanismo de defensa de ciertos derechos constitucionales, empezando, desde luego, por el derecho de propiedad, ya que evita que la ley tributaria pueda afectar irrazonable y desproporcionadamente la esfera patrimonial de las personas.

Asimismo, se encuentra directamente conectado con el derecho de igualdad en materia tributaria o, lo que es lo mismo, con el principio de capacidad contributiva, según el cual, el reparto de los tributos ha de realizarse de forma tal que se trate al a los iguales y desigual a los desiguales, por lo que las cargas tributarias han e recaer, en principio, donde exista riqueza que pueda ser gravada, lo que evidentemente implica que se tenga en consideración la capacidad personal o patrimonial de los contribuyentes" (STC 2727-2002-AA/TC).

En relación con el principio de Igualdad (explicito) el Tribunal Constitucional (2007) añade:

“20. La igualdad como derecho fundamental está consagrada por el artículo $2^{\circ}$ de la Constitución de 1993, (...) Contrariamente a lo que pudiera desprenderse de una interpretación literal, estamos frente a un derecho fundamental que no consiste en la facultad de las personas para exigir un trato igual a los demás, sino a ser tratado de igual modo a quienes se encuentran en una idéntica situación.

Constitucionalmente, el derecho a la igualdad tiene dos facetas: igualdad ante la ley e igualdad en la ley. La primera de ellas quiere decir que la norma debe ser aplicable por igual a todos los que se encuentren en la situación descrita en el supuesto de la norma; mientras que la segunda implica que un mismo órgano no puede modificar arbitrariamente el sentido de sus decisiones en casos sustancialmente iguales, y que cuando el órgano en cuestión 
considere que debe apartarse de sus precedentes, tiene que ofrecer para ello una fundamentación suficiente y razonable.

Sin embargo, la igualdad, además de ser un derecho fundamental, es también un principio rector de la organización del Estado social y democrático de Derecho y de la actuación de los poderes públicos. Como tal, comporta que no toda desigualdad constituye necesariamente una discriminación, pues no se proscribe todo tipo de diferencia de trato en el ejercicio de los derechos fundamentales; la igualdad solamente será vulnerada cuando el trato desigual carezca de una justificación objetiva y razonable. La aplicación, pues, del principio de igualdad, no excluye el tratamiento desigual; por ello, no se vulnera dicho principio cuando se establece una diferencia de trato, siempre que se realice sobre bases objetivas y razonables.” (STC 00009-2007-PI/TC - 00010-2007-PI/TC)

En ese sentido, este principio es importante para el desarrollo de esta investigación, considerando que lo que busca garantizar es que todos los contribuyentes en igualdad de condiciones se sometan a las mismas obligaciones y derechos, y por qué no decirlo, beneficios. Busca exigir que las exclusiones del ámbito de aplicación de una norma o el otorgamiento de beneficios del legislador se encuentren debidamente justificadas y que el rango de alcance incluya a todos los que tengan igual de condiciones, algunos llaman a este principio el de Generalidad.

En otras palabras, la potestad tributaria debe ejercerse respetando principios de razonabilidad y proporcionalidad, sobre todo al momento de fijarse la base imponible y la tasa del impuesto.

\subsubsection{El Principio de Equidad}

Habiendo revisado el punto anterior, la capacidad contributiva tiene como efecto el nacimiento de una obligación implícita: “el deber de contribuir", pero en proporción a sus ingresos (la carga tributaria debe ser de manera equitativa). El estado debe garantizar normas justas de proporciones razonables. 
Para Zavalla (2003):

Las consideraciones de equidad en un sistema tributario pueden ser abordadas desde varios enfoques. El primero, consiste en ver la equidad en dos dimensiones complementarias: la equidad horizontal y la equidad vertical. La primera se refiere a un tratamiento tributario igualitario para individuos en similares condiciones de ingresos; y la segunda, a una carga impositiva diferente para individuos con diferentes niveles de ingreso (pág. 149).

Este principio es importante en esta investigación a la hora que evaluemos la carga tributaria del contribuyente; por ejemplo, no se limita a las tasas impositivas aplicadas por régimen tributario, sino también al costo que tienen que asumir por el cumplimiento de las obligaciones formales.

\subsubsection{El deber de contribuir con el gasto público}

Al respecto el Tribunal Constitucional (2004) precisó que a:

"Todo tributo, le es implícito el propósito de contribuir con los gastos públicos, como una manifestación del principio de solidaridad que se encuentra consagrado implícitamente en la cláusula que reconoce al Estado peruano como un Estado Social de Derecho (artículo 43 de la Constitución)” (STC 0004-2004$\mathrm{AI} / \mathrm{TC})$.

En el sistema tributario peruano, vemos el cumplimiento de este deber y el principio de Solidaridad en varias obligaciones del contribuyente debidamente normadas. Por ejemplo:

- $\quad$ La obligación de pagar tributos: se rige por la capacidad contributiva donde el que más tiene, más paga, más contribuye al gasto público, aunque no necesariamente es el más beneficiado de los servicios públicos. 
- La obligación de ejecutar acciones, como parte de la relación jurídica con terceros, a fin de facilitar el proceso de recaudación. Por ejemplo, como agente de retenciones o percepciones.

- La obligación de brinda información, como parte de la relación jurídica con terceros, a fin de facilitar el proceso de recaudación y/o fiscalización. Por ejemplo, la Declaración Anual de Operaciones con Terceros - DAOT.

Este principio es importante en esta investigación al evaluar las formas en que la ampliación de la base tributaria, que se puede lograr con el Nuevo RUS, puede aportar al Gasto Público.

\subsubsection{El Principio de Economía en la Recaudación}

La Constitución del año 1979 consideraba explicitamente a la economía en la recaudación como un principio que regia a la tributación (articulo ${ }^{\circ} 139$ ). No obstante, esta no fue incluida en la constitución vigente.

Según Vidal H. (1998):

Este principio constitucional se resume en que los legisladores deben observar como regla directriz para la creación de nuevos tributos en nuestro país, un análisis previo a fin de verificar si el costo recaudatorio del tributo que se proyecta crear resulta importante en relación con el costo administrativo fiscal que va a representar la fiscalización y control de la evasión del mismo (pág. $364)$.

En otras palabras, la Potestad Tributaria debe ejercerse evaluando el costo beneficio de los tributos que se van a crear. La directriz general: lo que se recauda debe ser mayor al gasto en el que se incurre para lograrlo. Se debe evaluar la carga en las diferentes etapas de la existencia del tributo: antes de crearla, al reglamentarla, el de la Administración Tributaria al momento de ejecutarla, e incluso la carga tributaria que asumirá el contribuyente. Por ejemplo, el código tributario establece que se considera extinguida la deuda por onerosidad cuando los montos no justifiquen su cobranza. 
Es obligación de las Administraciones Tributarias dirigir sus acciones por un factor, cuya cuantificación no está definida, el "interés fiscal”, por lo que muchas veces sus acciones no llegan a los sectores fuera de esta estela de interés fiscal.

Al respecto Vidal H. añade que al legislar se "debería buscarse una mayor tecnificación y mejoramiento de la fiscalización de los tributos ya existentes, antes que la creación de nuevos impuestos sin poseer la infraestructura técnica para un adecuado control de su evasión y recaudación” (pág. 366).

Este principio es importante para esta investigación, ya que compartimos la opinión de Vidal H, antes de eliminar un tributo, o régimen tributario para nuestro caso de investigación, se debe evaluar que oportunidades de mejora y perfeccionamiento se pueden dar a este régimen; considerando que, como analizaremos en el tercer capítulo de este trabajo de investigación, es lo que vienen haciendo otros países.

\subsubsection{El Principio de Certeza}

La Constitución del año 1979 consideraba explícitamente a la certeza como un principio que regía a la tributación (articulo ${ }^{\circ} 139$ ). No obstante, esta no fue incluída en la constitución vigente.

Vidal C. (1996) precisó que: "La certeza, etimológicamente significa tener conocimiento seguro y claro de una cosa". Por lo que:

Juridica y tributariamente, el contribuyente debe tener conocimiento seguro y claro de su obligación frente a la norma que rige el tributo. (pág. 12).

(...) con ella debe el contribuyente estar en la posibilidad de conocer en forma pronta y definitiva sus obligaciones y derechos, en especial la cuantía de su deuda tributaria. (...) elemento fundamental de la seguridad juridica, la cual abarca otros principios como el de legalidad, igualdad, tutela jurisdiccional, irretroactivadad" (pág. 13). 
Concluyendo que:

Para lograr la certeza ideal, el Poder Legislativo y el Poder Ejecutivo en caso de delegación, deben cuidar que la ley tributaria sea clara y precisa, para su fácil y correcta aplicación por el contribuyente, haciendo intervenir en su estudio y preparación a personal técnico especializado cuando el caso lo requiera (pág. 24).

En otras palabras, este principio busca garantizar que la normativa tributaria se caracterice por ser clara y precisa, definiendo claramente los elementos de tributo: el sujeto, el hecho imponible, la base imponible, la alícuota, fecha, plazo y modalidades de pago, inafectaciones, exoneraciones y beneficios en general, infracciones posibles, sanciones aplicables y recursos impugnatorios que proceden frente a una actuación de la administración tributaria. La normativa tributaria debe permitir la predictibilidad en el desarrollo de la actuación de la administración tributaria y los contribuyentes.

\subsubsection{El Principio de Simplicidad}

Este principio busca que los sistemas tributarios sean simples, con la menor cantidad de tributos, obligaciones tributarias fáciles de entender para los contribuyentes, y por ende, fáciles de cumplir.

Díaz S. (2011) sostiene que:

Muchos países que han logrado éxito con sus sistemas tributarios reconocen que se ha debido al grado de simplicidad que mantienen ya que esto ha conllevado a mayores incentivos para participar del sistema Tributario Formal, en otras palabras, menores niveles de informalidad y mayores de cumplimiento tributario (menor evasión).

Comenta sobre el Régimen Simplificado Ecuatoriano:

Los costos de cumplimiento que acarrea (...) al ser bajos atraen a los agentes objetivos, ya que mientras más bajos sean representarán 
menos Presión Fiscal Indirecta. Entre las características que ayudan este principio están el no estar obligado a llevar contabilidad, no llenar formulario alguno de IR e IVA, la cuota es fija no existe cálculo para su obtención, entre otras (pág. 161).

En el Perú, según los lineamientos de Política Tributaria establecidos (Ministerio de Economía y Finanzas - MEF), se busca la de consolidación de este principio con la simplificación del actual Sistema Tributario, aunque sus medidas legislativas demuestren lo contrario.

\subsubsection{El Principio de respeto de los derechos fundamentales de la persona}

El respeto a los derechos fundamentales que se enumeran el artículo $2^{\circ}$ de la Constitución, son un precepto que por mandato expreso debe cumplir el Estado al ejercer su Potestad Tributaria. No obstante, aunque no incluidos en este artículo, la constitución también detalla otros derechos, que se perfilan como fundamentales, en el Titulo III Régimen Económico, Capítulo I - Los Principios Generales, detalla los derechos de los ciudadanos vinculados al desarrollo de actividades económicas que debe garantizar el Estado al ejercer su Potestad Tributaria.

"El Estado brinda oportunidades de superación a los sectores que sufren cualquier desigualdad; en tal sentido promueve las pequeñas empresas en todas sus modalidades” Art. 59 (Constitución Política del Perú, 1993).

El Estado debe estimular el desarrollo de la actividad económica, garantizando un entorno de libre competencia.

Este principio es de los más importantes para esta investigación, dado que trataremos de sustentar la necesidad de un régimen tributario dirigido a personas naturales que recién inician o van a iniciarse en la actividad económica, que no vean en el sistema tributario una traba para dar inicio a sus actividades. 


\subsection{Nuevo Régimen Único Simplificado - Nuevo RUS}

En este trabajo no vamos a desarrollar todo el contenido normativo de este régimen tributario, pero si vamos a puntualizar sobre aquellas características que son una oportunidad de mejora y el proceso involutivo desde su creación.

\subsubsection{Decreto Legislativo $\mathbf{N}^{\circ} \mathbf{9 3 7}^{1}$}

Con el que se crea el Nuevo y se deroga el Régimen Único Simplificado. Concebido como "un régimen tributario promocional para las pequeñas empresas que facilite el cumplimiento de sus obligaciones y amplíe la base tributaria".

La base tributaria está compuesta por los contribuyentes que se encuentran inscritos ante la Administración Tributaria y que cumplen con su obligaciones tributarias. Es decir, que tácitamente se entiende que el Nuevo RUS es un régimen dirigido a aquellos contribuyentes que no se encuentran inscritos ante la Administración Tributaria.

Este régimen tributario permite a los contribuyentes liquidar sus rentas e impuestos sobre ventas de manera conjunta.

El Nuevo RUS está dirigido:

- A personas naturales o sucesiones indivisas que realizan ventas de mercaderías o servicios a consumidores finales; y

- A personas naturales que desarrollan un oficio, actividad laboral que no requiere de título profesional universitario para ejercerlo.

Los contribuyentes de este régimen pueden emitir solo documentos que no otorguen derecho a crédito fiscal o ser utilizados para sustentar costo o gasto para efectos tributarios (boletas de venta, tickets o cintas emitidas por máquinas registradoras) dado que le van a vender a consumidores finales 
que no tienen la necesidad de, valga la redundancia, crédito fiscal o sustentar costo o gasto.

No obstante, están obligados a exigir facturas, tickets o cintas emitidas por máquinas registradoras $\mathrm{u}$ otros documentos autorizados que permitan ejercer el derecho al crédito fiscal, aunque no lo utilicen, o ser utilizados para sustentar costo o gasto para efectos tributarios de acuerdo a las normas pertinentes, a sus proveedores por las compras de bienes y por la prestación de servicios; así como recibos por honorarios, en su caso. Los contribuyentes del Nuevo RUS solo pueden ser clientes de contribuyentes de otros regímenes tributarios.

Aunque no se encuentran obligados a llevar registros contables, tienen la obligación de conservar los comprobantes de pago emitidos y/o recibidos, ordenados de manera cronológica como sustento de las declaraciones mensuales.

La norma lista las actividades excluidas de este régimen, varias de ellas por su alto nivel de informalidad (organización de espectáculo público, servicio de transporte terrestre nacional o internacional de pasajeros, venta a consignación, entre otros); o bienes y/o servicios cuya comercialización requieren un nivel de control de mayores exigencias por ser de interés del estado (gasolina, afectos al Impuesto Selectivo al Consumo).

Creado con diez (10) categorías (Tabla 1.1): cinco (5) para los sujetos que exclusivamente obtengan rentas de tercera categoría actividades de comercio y/o industria, y cinco (5) para los sujetos que obtengan rentas de tercera y/o cuarta categoría por la realización de actividades de oficio. El régimen era calculado y de vigencia cuatrimestral, con los siguientes parámetros: Ingresos brutos, adquisiciones, consumo de energía eléctrica (kw-h), consumo de servicio telefónico y número máximo de personas afectadas a la actividad. Vencido el cuatrimestre calendario los contribuyentes debían recategorizarse según correspondía.

Tabla 1.1 Tablas de categorías del Nuevo RUS creado con Decreto Legislativo $\mathbf{N}^{\circ} 937$ 


\begin{tabular}{|c|c|c|c|c|c|c|c|}
\hline \multicolumn{7}{|c|}{$\begin{array}{c}\text { Parámetros aplicable a los sujetos que exclusivamente obtengan rentas de tercera categoría } \\
\text { provenientes de la realización de actividades de comercio y/o industria }\end{array}$} & \multirow[b]{2}{*}{$\begin{array}{c}\text { Cuota } \\
\text { Mensual } \\
\text { S/. }\end{array}$} \\
\hline Categoría & $\begin{array}{c}\text { Total } \\
\text { Ingresos } \\
\text { brutos en un } \\
\text { cuatrimestre } \\
\text { calendario } \\
\text { (hasta } \mathrm{S} / . \text { ) }\end{array}$ & $\begin{array}{c}\text { Total } \\
\text { Adquisiciones } \\
\text { en un } \\
\text { cuatrimestre } \\
\text { calendario } \\
\text { (hasta } \mathrm{S} / . \text { ) }\end{array}$ & $\begin{array}{l}\text { Consumo de } \\
\text { energía } \\
\text { eléctrica en un } \\
\text { cuatrimestre } \\
\text { calendario } \\
\text { (hasta kw-h.) }\end{array}$ & $\begin{array}{c}\text { Consumo de } \\
\text { servicio } \\
\text { telefónico en } \\
\text { un } \\
\text { cuatrimestre } \\
\text { calendario } \\
\text { (hasta } S / . \text { ) }\end{array}$ & $\begin{array}{c}\text { Precio } \\
\text { unitario } \\
\text { máximo } \\
\text { de venta } \\
\text { (hasta } \\
\text { S/.) } \\
(*)\end{array}$ & $\begin{array}{c}\text { Número } \\
\text { máximo de } \\
\text { personas } \\
\text { afectadas a } \\
\text { la actividad } \\
\text { (hasta) }\end{array}$ & \\
\hline 11 & 14,000 & 14,000 & 2,000 & 1,200 & 250 & 2 & 20 \\
\hline 12 & 24,000 & 24,000 & 2,000 & 1,200 & 250 & 3 & 50 \\
\hline 13 & 36,000 & 36,000 & 3,000 & 2,000 & 500 & 4 & 140 \\
\hline 14 & 54,000 & 54,000 & 3,500 & 2,700 & 500 & 4 & 280 \\
\hline 15 & 80,000 & 80,000 & 4,000 & 4,000 & 500 & 5 & 500 \\
\hline
\end{tabular}

\begin{tabular}{|c|c|c|c|c|c|c|c|}
\hline \multicolumn{7}{|c|}{$\begin{array}{c}\text { Parámetros aplicable a los sujetos que obtengan rentas de tercera y/o cuarta categoría por la } \\
\text { realización de actividades de oficios, según corresponda }\end{array}$} & \multirow[b]{2}{*}{$\begin{array}{c}\text { Cuota } \\
\text { Mensual } \\
\text { S/. }\end{array}$} \\
\hline Categoría & $\begin{array}{c}\text { Total } \\
\text { Ingresos } \\
\text { brutos en un } \\
\text { cuatrimestre } \\
\text { calendario } \\
\text { (hasta } \mathrm{S} / \text {.) }\end{array}$ & $\begin{array}{c}\text { Total } \\
\text { Adquisiciones en } \\
\text { un cuatrimestre } \\
\text { calendario (hasta } \\
\text { S/.) }\end{array}$ & $\begin{array}{l}\text { Consumo de } \\
\text { energía } \\
\text { eléctrica en un } \\
\text { cuatrimestre } \\
\text { calendario } \\
\text { (hasta kw-h) }\end{array}$ & $\begin{array}{c}\text { Consumo de } \\
\text { servicio } \\
\text { telefónico en } \\
\text { un } \\
\text { cuatrimestre } \\
\text { calendario } \\
\text { (hasta } S / . \text { ) }\end{array}$ & $\begin{array}{c}\text { Precio } \\
\text { unitario } \\
\text { de } \\
\text { venta } \\
\text { (hasta } \\
\text { S/.) }{ }^{(1)}\end{array}$ & $\begin{array}{c}\text { Número } \\
\text { máximo de } \\
\text { personas } \\
\text { afectadas a } \\
\text { la actividad } \\
\text { (hasta) }^{(2)}\end{array}$ & \\
\hline 21 & 14,000 & 7,000 & 2,000 & 1,200 & 250 & 2 & 20 \\
\hline 22 & 24,000 & 12,000 & 2,000 & 1,200 & 250 & 3 & 50 \\
\hline 23 & 36,000 & 18,000 & 3,000 & 2,000 & 500 & 4 & 180 \\
\hline 24 & 54,000 & 27,000 & 3,500 & 2,700 & 500 & 4 & 380 \\
\hline 25 & 80,000 & 40,000 & 4,000 & 4,000 & 500 & 5 & 600 \\
\hline
\end{tabular}

Elaboración propia.

Fuente: SUNAT

\subsubsection{Decreto Legislativo $\mathrm{N}^{\circ} \mathbf{9 6 7}^{2}$}

Con esta modificatoria se reduce a cinco (5) las categorías progresivas (Tabla 1.2) de este régimen, sin diferenciar tipo de renta o actividad, o considerar parámetros diferentes al límite de ingresos brutos y/o 
adquisiciones. Asimismo, la recategorización será por el límite establecido mensual.

Tabla 1.2 Tabla de categorías de Nuevo RUS vigentes hasta el 31 de diciembre 2016

\begin{tabular}{|c|c|c|c|}
\hline \multirow{2}{*}{ CATEGORIAS } & \multicolumn{3}{|c|}{ PARAMETROS } \\
\cline { 2 - 4 } & $\begin{array}{c}\text { Total Ingresos } \\
\text { Brutos } \\
\text { Mensuales } \\
\text { (Hasta S/ })\end{array}$ & $\begin{array}{c}\text { Total } \\
\text { Adquisiciones } \\
\text { Mensuales } \\
\text { (Hasta S/ })\end{array}$ & $\begin{array}{c}\text { Cuota } \\
\text { Mensual } \\
\text { S/. }\end{array}$ \\
\hline 1 & 5,000 & 5,000 & 20 \\
\hline 2 & 8,000 & 8,000 & 50 \\
\hline 3 & 13,000 & 13,000 & 200 \\
\hline 4 & 20,000 & 20,000 & 400 \\
\hline 5 & 30,000 & 30,000 & 600 \\
\hline
\end{tabular}

Elaboración propia.

Fuente: SUNAT

Se ha mantenido en el tiempo la posibilidad de que un contribuyente pueda ubicarse en una categoría denominada "Categoría Especial", cuando se dediquen únicamente a la venta de frutas, hortalizas, legumbres, tubérculos, raíces, semillas y demás bienes especificados en el Apéndice I de la Ley del Impuesto General a las Ventas (IGV) e Impuesto Selectivo al Consumo (ISC), realizada en mercados de abastos; ó, al cultivo de productos agrícolas y que vendan sus productos en su estado natural. Siempre que el total de sus ingresos brutos y de sus adquisiciones anuales no exceda actualmente, cada uno, de S/ 60,000 (SUNAT).

\subsection{Definición de Informalidad}

Informal es el "que no guarda las formas y reglas prevenidas" (RAE) como el vendedor ambulante. En el mismo sentido Peñaranda (2014), define al sector informal como el "conjunto de unidades productivas no constituidas en sociedad y que no se encuentran registradas en SUNAT” (pág. 7). 
Según el Instituto Nacional de Estadística e Informática - INEI (2016), Perú funciona aproximadamente con 6,6 millones de unidades productivas desenvolviéndose en el sector informal de la economía, las que representan una quinta parte de producto bruto interno (PBI) del país. Añade que, en la última década el sector informal ha representado en promedio $19 \%$ de la economía. En donde ha habido una ligera mejora es en el empleo informal, aunque este sigue siendo predominante, pues pasó del 79,9\% del total a 73,2\%.

Para Gleiser (2014):

El alto nivel de la informalidad no disminuye porque más allá de los discursos no hay una política de Estado que haga atractiva la formalidad y que simplifique toda la normativa. "Persisten las trabas burocráticas y un sistema tributario y laboral que no apoya el crecimiento de la pequeña empresa, sino que hace que esta se estanque".

Para Luna (2016):

Los problemas de las PYME son: el llenado de impuestos, deben poder hacerlo por medios digitales, desde su celular, un formulario más simple, un impuesto sobre las ventas y no sobre la renta. "Si el estado y el sector privado no van juntos no vamos a poder vencer la informalidad de este país". "Que haya más competitividad de las PYME peruanas de herramientas innovadoras y un trabajo conjunto, estado y sector privado. Trabajar juntos para promover la formalización”, agregó.

Acevedo (2007) sostiene que:

Cuando se le pregunta a un empresario que está en la informalidad por qué no pasa al lado de los formales, usualmente responde que ser formal no le trae ningún beneficio y, además, el costo para formalizarse es muy alto para sus intereses. Las causas de este alto grado de informalidad son varias, entre ellas, la falta de políticas públicas que generen incentivos para la formalización. Actualmente, muchas de las pequeñas empresas (que tienden a ser informales) no ven en la formalidad un beneficio, sino más bien un perjuicio por los altos costos que son necesarios para realizar trámites o para cumplir una legislación muy estricta. Sugiriendo que se debe hacer atractiva la formalidad, mediante incentivos apropiados y para ello se deben revisar 
los programas orientados a la microempresa y mejorarlos para que, a través de su implementación, se promueva la formalidad.

Según Moreno (2002):

Se entiende por informalidad aquellas actividades económicas en las que no se respetan las formas establecidas en la legislación vigente como, por ejemplo, no inscribirse en el Registro Único de Contribuyentes, no obtener Licencia Municipal de Funcionamiento o no presentar declaraciones juradas de impuestos cuando corresponde.

Pero, como en todos los aspectos de la vida, antes de tomar una decisión, hacemos (consciente o inconscientemente) un análisis del costo-beneficio de las alternativas que se nos presentan. Dos son los aspectos en los que se debe trabajar con la finalidad de combatir la informalidad y ampliar la base tributaria: la reducción de costos y el incremento de beneficios de la formalidad.

Asimismo, Moreno (2002) señala que entre los beneficios que conlleva trabajar de manera forma están:

a. Permitir ser sujeto de crédito para el sistema financiero. Una de las condiciones o requisitos exigidos a las personas para obtener un crédito, ya sea que trabajen independientemente o tengan un negocio, consiste en la demostración de los ingresos percibidos y el respeto de los compromisos asumidos. En tal sentido será indispensable inscribir la actividad económica en los registros de la SUNAT y cumplir con las obligaciones tributarias dispuestas por la legislación vigente a fin de poder obtener un préstamo de las instituciones del sistema financiero.

b. Evita ser objeto de sanciones por la inobservancia de las normas vigentes, incluyendo las de carácter tributario.

c. Abrir las posibilidades de una mayor demanda de los productos que se venden o servicios que se prestan. Trabajar formalmente permite contar con mayor número de clientes y, por ende, de ingresos, ya que siempre las empresas formales y entidades del 
Estado eligen como proveedores a personas que desarrollan su actividad económica de manera formal.

d. Es una manera efectiva de redistribuir la riqueza (más tributos paga quien mayor capacidad contributiva o ingresos tiene). El correcto y oportuno pago de los tributos permite al Estado obtener los recursos para buscar la satisfacción de las necesidades básicas de aquel sector de la población de menores ingresos.

e. Brinda la autoridad moral para exigir servicios públicos de calidad. Cumplir con cada una de las obligaciones que tenemos como ciudadanos nos faculta a exigir nuestros derechos.

Las opiniones citadas llegan a la misma conclusión, de que no sólo basta con facilitar la formalización, si no que se requiere incentivar al contribuyente que viene trabajando desde la informalidad, a fin de que se sienta atraído por la formalización. Nuestra opinión no difiere de las citadas, por ejemplo, el sólo hecho de bajar las tasas de impositivas no hace atractiva la formalidad para aquellos que actualmente no pagan impuesto (reducir la carga tributaria de aquellos que no tienen carga tributaria no es un incentivo).

Según Arias M. (2018) "La evasión tributaria es dejar de pagar impuestos que corresponden a hechos económicos, que efectivamente han ocurrido y que están expresamente gravados de acuerdo con la ley tributaria. En esos casos, se trata de una violación directa a dicha ley". Por lo que la reducción de la informalidad también va a tener un efecto en la reducción de la evasión tributaria del país.

\subsection{Estimación Directa y Estimación Objetiva del impuesto a la renta.}

Para la determinación de la base imponible del impuesto a la renta los regímenes tributarios del Perú se dan en base a dos (2) tipos de estimación:

Estimación Directa o real, la base imponible se calcula resultado de la acumulación de los ingresos, gastos y costos en un periodo específico. Se busca aplicar con exactitud rigurosa la capacidad contributiva de los sujetos obligados. En el Perú 
por tercera categoría: Régimen General (ordinaria), Régimen Especial de Renta y, a partir del 2017, el Régimen Tributario MYPE (simplificada).

Estimación Objetiva, su cálculo es resultado de una medición aproximada, en base a elementos cuantitativos contrastables, como cantidad de trabajadores, o metros cuadrados del área que ocupa el negocio, ventas realizadas en un periodo específico. En el Perú por tercera categoría solo tenemos el Nuevo Régimen Único Simplificado.

La Estimación Objetiva es una solución para la complejidad de la determinación directa ordinaria, toma elementos cuantitativos que tienen en común el grupo de contribuyentes objetivo. El Estado recurre a este tipo de simplificación a fin de capturar las manifestaciones de riqueza que si se pretendiera captar por el régimen ordinario resultaría una tarea infructuosa. 


\section{CAPÍTULO II: LA REFORMA TRIBUTARIA DEL 2016}

De lo expuesto en el punto “1.2.1 El Principio de Reserva de Ley y Principio de Legalidad" nos queda claro que en la delegación de facultades al Poder Ejecutivo para legislar en materia tributaria el Poder Legislativo lo acompaña de la frase: "Tú propones, pero yo dispongo".

El 08 de setiembre del 2016 con Oficio No 108-2016-PR el Presidente de la Republica, a través del Consejo de Ministros solicita al Congreso de la Republica la delegación de facultades para legislar en materia de reactivación económica y formalización.

En este trabajo de investigación nos limitaremos a desarrollar el análisis de la reforma tributaria en materia de formalización.

\subsection{Antecedentes}

El Partido Político Peruanos por el Kambio (2016), partido político de gobierno, responsable de la reforma tributaria que se analizara en este capítulo, expuso en su plan de gobierno:

La gran mayoría de las empresas en el Perú son pequeñas y medianas. Casi el $70 \%$ del empleo proviene de empresas informales que no pagan beneficios a sus trabajadores. Es fundamental, si queremos tener una reactivación en toda la economía peruana, facilitar la formalización de este sector empresarial. Hay evidencia internacional que demuestra que impuestos altos favorecen la evasión y la informalidad.

Concluyendo que lo que se necesita es la creación de Régimen especial para las empresas pequeñas que se formalicen: (pág. 7). Ley de incentivo para la pequeña y mediana empresa, con un tratamiento tributario especial y un régimen que permitirá formalizar la economía y generar más empleo. 
Alineado a una nueva política tributaria que baje las tasas impositivas, pero que aumente la recaudación (pág. 132).

Añade:

Nuevo régimen se complementará con los otros dos regímenes orientados a las pequeñas y medianas empresas, el régimen especial del impuesto a la renta (RER) y el régimen único simplificado (RUS) (pág. 138).

Con Oficio N $\mathrm{N}^{\mathrm{0}}$ 108-2016-PR, con el que se solicitó la delegación de facultades para legislar en materia de reactivación económica y formalización, se argumentó:

El Perú no podrá solucionar sus graves problemas económicos, políticos y sociales mientras la mayoría del país y trabajando en el sector informal. Los altos niveles de informalidad son perjudiciales para nuestro país porque no solo afectan su crecimiento, sino también la recaudación de impuestos. Resulta necesario entonces reducir los costos relativos de pertenecer a la formalidad, perfeccionando el régimen jurídico-tributario de las micro y un segmento de las pequeñas empresas y a las personas de menores recursos, simplificando y mejorando los procesos de recaudación, incentivando a las personas para que sean agentes de la formalización (...). Ahora bien, una estrategia efectiva de formalización supone, además, incrementar los beneficios relativos de pertenecer a la formalidad. Esto se logrará mediante la mejora en la calidad y acceso de los servicios públicos (Proyecto de Ley 228/2016-PE, 2016).

El congreso, en lo referente a reactivación económica y formalización, otorga las siguientes facultades al Poder Ejecutivo:

\section{Artículo 2. Materia de la delegación de facultades legislativas}

En el marco de la delegación de facultades a la que se refiere el artículo 1 de la presente Ley, el Poder Ejecutivo está facultado para:

1) Legislar en materia de reactivación económica y formalización a fin de: 
a) Ampliar la base tributaria e incentivar la formalización a través de la modificación de tasas impositivas, mayor simplicidad y mejores procesos de recaudación; establecer incentivos para que las personas naturales exijan comprobantes de pago; simplificar la estructura tributaria empresarial [negritas añadidas] (...). Las medidas tributarias que se aprobarán en el marco de la delegación de facultades son las siguientes: $(\ldots)$

a.2) Modificar la Ley del Impuesto a la Renta y demás normas que regulen el Impuesto a la Renta para: (...)

ii. Modificar la determinación del Impuesto a la Renta de los contribuyentes domiciliados en lo referente a las rentas del trabajo y rentas de fuente extranjera, manteniendo la deducción de siete (7) Unidades Impositivas Tributarias.

Adicionalmente la deducción de al menos una (1) UIT [Unidad Impositiva Tributaria] en gastos tales como salud, educación, vivienda, servicios profesionales, servicios de agua y saneamiento, energía eléctrica y telefonía, sustentados en comprobantes de pago [negritas añadidas]. (...)

a.4) Establecer un régimen jurídico-tributario especial para las micro y pequeñas empresas, incluyendo tasas progresivas aplicadas a la utilidad o los ingresos, a elección de cada contribuyente. No podrá legislarse en materia de declaración y pago del Impuesto General a las Ventas (IGV), ni modificar el Nuevo Régimen Único Simplificado en lo que se refiere a la Categoría Especial y los tramos 1 y 2 de las Tablas del referido sistema en lo referente al importe de la cuota y tramos de ingresos por compras y ventas" (Ley No 30506, 2016).

Denegándole "establecer regímenes especiales de determinación, declaración y pago" (Proyecto de Ley 228/2016-PE, 2016).

\subsection{Exposición de Motivos del Poder Ejecutivo}


En la Exposición de motivos del Proyecto de Ley 228/2016-PE (2016) el Poder Ejecutivo precisó que el objetivo de las reformas a implementar es ampliar la base tributaria y perfeccionar los procesos de recaudación y fiscalización. Estas medidas coadyuvarán a incrementar la formalización. En Particular, se buscará la simplificación y reducción de la carga tributaria y los costos de cumplimiento.

El Ministerio de Economía y Finanzas, en adelante MEF, en el documento denominado Exposición de motivos (2016), tratando de alinear su propuesta a los límites establecidos por el Poder legislativo, argumenta:

Con el decreto legislativo $\mathrm{N}^{\circ} 1258$, que modifica la Ley del Impuesto a la Renta, se otorga a los contribuyentes (personas naturales) perceptores de rentas de trabajo deducir tres (3) Unidades Impositivas Tributarias adicionales, a los siete (7) Unidades Impositivas Tributarias ya establecidos, sustentado en comprobantes de pago. Justifica esta medida indicando:

\section{La emisión de comprobantes de pago coadyuva a combatir la evasión} e informalidad [negritas añadidas] ya que permite documentar las operaciones que realiza el vendedor o prestador de servicios a efectos que cumpla con sus obligaciones tributarias, sirviendo de esta forma como una herramienta de control para la Administración Tributaria [negritas añadidas].

En atención a ello, el artículo $97^{\circ}$ del Código Tributario dispone que las personas que compren bienes o reciban servicios están obligadas a exigir que se les entregue los comprobantes de pago por las compras efectuadas o por los servicios recibidos, ya sean impresos o emitidos electrónicamente.

Sin embargo, a pesar de la existencia de dicha obligación algunas personas naturales no tienen una cultura tributaria de exigir la emisión de comprobantes cuando realizan operaciones.

Nótese que en el Estado Social y Democrático de Derecho el ciudadano no solo tiene el deber de pagar tributos sino que también asume labores de colaboración con la Administración Tributaria a fin de garantizar que todos participen de acuerdo a su capacidad contributiva en el financiamiento del gasto público. (pág. 3) 
Por lo señalado, resulta necesario establecer medidas para incentivar que las personas naturales cumplan con su deber de exigir comprobantes de pago ya que de esta forma se coadyuva a reducir los índices de evasión e informalidad [negritas añadidas].

Una forma de lograr dicho objetivo es permitiendo que los trabajadores (dependientes y/o independientes) puedan deducir determinados gastos para determinar el impuesto a la renta aplicable a las rentas del trabajo siempre que estén sustentados con comprobantes de pago. Nótese que esta medida es idónea considerando que existen 1,5 millones de trabajadores que tendrían incentivos para cumplir con su deber de solicitar comprobantes de pago en los sectores de la economía donde existen un alto grado de evasión e informalidad, fortaleciendo además la cultura tributaria de exigir dichos documentos. (pág. 4)

Lo cuestionable de esta medida fue incluir los intereses de créditos hipotecarios, servicio brindado por las entidades del Sistema Financiero. ¿Qué puede haber el Perú más formal que nuestro Sistema Financiero? ¿Cuántos emisores del sistema financiero pueden haber, que la Administración requiere apoyo de los contribuyentes para exigir comprobante de pago?

Para el decreto legislativo $\mathrm{N}^{\circ} 1269$, con el que se Crea el Régimen MYPE Tributario, hace hincapié en el que:

El problema que tiene el Sistema Tributario Peruano es la existencia de varios regímenes tributarios a los cuales pueden acogerse las empresas existentes en nuestro país, las empresas que tienen un ingreso neto anual no mayor a las 1700 UIT [Unidades Impositivas Tributarias] (pág. 1),

Lo que resulta contradictorio, considerando que con la reforma tributaria se crea un nuevo régimen tributario del impuesto a la renta. Asimismo, enumera un sinfín de situaciones aisladas que buscan justificar la creación de un nuevo régimen.

Afirman que los regímenes tributarios (Nuevo RUS y RER) no cumplen con la finalidad para la que fueron creados debido a que no resultan atractivos para los contribuyentes, pues ellos prefieren acogerse al Régimen General del Impuesto a la Renta tributando sobre una tasa más elevada respecto de sus rentas o, en el peor 
de los casos, no se acogen a ningún régimen tributario, prefiriendo mantenerse en la informalidad (pág. 2).

Toma como referencia España, añadiendo que el incentivo para la formalización está en reducir la carga tributaria durante sus "primeros años”. Así como, tasas progresivas en este y varios países (pág. 3).

El Análisis Costo Beneficio proyecta una reducción de la recaudación de S/.1`500,000, resultado de la reducción de la carga tributaria de 700 mil contribuyentes, entiéndase, contribuyentes formales de otros regímenes que se acogerán a este nuevo régimen. (pág. 7). Al respecto, Luna (2016) advierte que se deben medir también "los costos fiscales que reducirían los recursos en salud y educación".

Para el decreto legislativo $\mathrm{N}^{\circ} 1270$, que elimina 3 categorías (en base a los ingresos) de Nuevo RUS, el MEF añade que durante el ejercicio 2015, se advierte que la gran mayoría de los contribuyentes con ingresos de 0 a 100 UIT [Unidades Impositivas Tributarias] tributa conforme a la categoría 1 del Nuevo RUS, esto es pagando un impuesto mensual de S/.20 (pág. 1).

Concluye, que teniendo en cuenta que la mayoría de contribuyentes generadores de tercera categoría percibe ingreso y paga impuestos similares a los que podrían percibir las categorías 1 y 2 del Nuevo RUS se opta por conservar solo dichas categorías en la legislación, así como la categoría especial, y eliminar las categorías 3, 4 y 5; manteniendo inalterable el tramo en función a ingresos y adquisiciones para las categorías 1 y 2 [negritas añadidas] (pág. 2). Justificando los límites establecidos por el Poder Legislativo en la delegación de facultades.

Para el MEF, esta modificación del Nuevo RUS no ocasionaría costo fiscal alguno para el estado, dado se "mejora" la estructura tributaria y coadyuva a la simplificación. Asimismo, el efecto sobre la recaudación es positivo independientemente del régimen en el que ingresen, no obstante, considerando que se trata únicamente de 12 mil contribuyentes, la mayor recaudación por efecto de esta migración no compensa el costo que implica la aplicación del Régimen MYPE Tributario (pág. 4).

La SUNAT (2017) informó que "más de 16 mil contribuyentes que al 31 de diciembre del 2016 se encontraban en las categorías 3, 4 y 5 del Nuevo RUS que 
han sido eliminadas" debieron optar, a partir del periodo enero 2017, por "acogerse a un régimen tributario que se ajuste a la actividad económica que viene realizando actualmente, siendo una de las opciones, el Régimen MYPE Tributario”.

\subsection{Decreto Legislativo No 1258: Deducción Adicional del Impuesto a la Renta para Personas Naturales}

El objeto de la modificación tributaria, aprobada con este decreto legislativo, es el mismo que del régimen tributario Nuevo RUS, pero te dice como lo va a hacer:

Ampliar la base tributaria e incentivar la formalización [negritas añadidas] a través de la modificación de la tasa del impuesto a la renta aplicable a las ganancias de capital obtenidas por personas naturales y sucesiones indivisas no domiciliadas por la enajenación de inmuebles situados en el país, así como establecer incentivos para que las personas naturales domiciliadas exijan comprobantes de pago [negritas añadidas] permitiendo la deducción de gastos de las rentas del trabajo (Decreto Legislativo $\left.\mathrm{N}^{\mathrm{o}} 1258,2016\right)$.

Con la entrada en vigencia de este decreto legislativo, se autoriza la deducción adicional de tres (3) Unidades Impositivas Tributarias a las personas naturales perceptoras de rentas de cuarta y quinta categoría, por los conceptos detallados en la Tabla 2.1.

Tabla 2.1 Gastos adicionales deducibles del Impuesto a la Renta para Personas Naturales

\begin{tabular}{|c|c|c|}
\hline $\begin{array}{c}\text { Conceptos incorporados al } \\
\text { artículo } 46^{\circ} \text { del Texto }\end{array}$ & Limite & \\
Único Ordenado de la Ley & Deducible & Sector "INFORMAL" \\
del Impuesto a la Renta & & \\
\hline
\end{tabular}

Aprobado por el Decreto Supremo N 179-2004-EF y normas modificatorias. 


\begin{tabular}{|l|l|l|}
\hline $\begin{array}{l}\text { a) El arrendamiento de } \\
\text { inmuebles }\end{array}$ & $30 \%$ & $\begin{array}{l}\text { Personas Naturales generadoras de } \\
\text { rentas de primera categoría que no } \\
\text { declaran. }\end{array}$ \\
\hline $\begin{array}{l}\text { b) Los intereses de créditos } \\
\text { hipotecarios para primera } \\
\text { vivienda. }\end{array}$ & $100 \%$ & $\begin{array}{l}\text { Entidades del Sector Financiero } \\
\text { iinformales? que otorgan créditos } \\
\text { hipotecarios. }\end{array}$ \\
\hline $\begin{array}{l}\text { c) Los honorarios } \\
\text { profesionales de médicos y } \\
\text { odontólogos }\end{array}$ & $30 \%$ & $\begin{array}{l}\text { Personas Naturales generadoras de } \\
\text { rentas de cuarta categoría por el } \\
\text { ejercicio de una profesión, por } \\
\text { servicios al contribuyente y derecho } \\
\text { habientes. }\end{array}$ \\
\hline $\begin{array}{l}\text { d) Los servicios prestados } \\
\text { por perceptores de rentas de } \\
\text { cuarta categoría }\end{array}$ & $30 \%$ & $\begin{array}{l}\text { Personas Naturales generadoras de } \\
\text { rentas de cuarta categoría, } \\
\text { especificados por el MEF con } \\
\text { Decreto Supremo No 399-2016-EF } \\
\text { publicado el 31.12.2016. }\end{array}$ \\
\hline $\begin{array}{l}\text { E) aportaciones a respecto de los } \\
\text { trabol hogar }\end{array}$ & $100 \%$ & $\begin{array}{l}\text { Los empleadores de trabajadores del } \\
\text { hogar. }\end{array}$ \\
\hline
\end{tabular}

Elaboración Propia.

Fuente: Decreto Legislativo No 1258

Aunque comparten el mismo objeto, esta norma no estuvo dirigida a formalizar a generadores de renta de Tercera Categoría, a los que va dirigido en Nuevo RUS.

Esta parte de la reforma tributaria solo estuvo vigente para los ejercicios $2017 \mathrm{y}$ 2018:

- El literal b) del artículo $46^{\circ}$ del Texto Único Ordenado de la Ley del Impuesto a la Renta fue derogado con el Decreto Legislativo $N^{\circ} 1381$, publicado el 24 de agosto del 2018, que entro en vigencia el 1 de enero del 2019.

- El Decreto Supremo N²48-2018-EF, publicado el 3 de noviembre del 2018, deroga el Decreto Supremo No 399-2016-EF, e incluye entre los gastos a 
deducir a partir del 1 de enero del 2019, los gastos por restaurantes y hoteles, según la página web de SUNAT, con un límite deducible del $15 \%$.

Con estas modificaciones, al incluir "restaurantes y hoteles", va dirigido a contribuyentes generadores de renta de tercera categoría. "Pero", porque esta modificatoria (Decreto Supremo $\mathrm{N}^{\circ} 248-2018-\mathrm{EF}$ ) tiene varios peros:

- La redacción de la norma se destaca por no cumplir los principios de simplicidad y certeza:

(...) también son deducibles como gasto el quince por ciento (15\%) de los importes pagados por concepto de los servicios comprendidos en la división 55 de la Sección H de la Clasificación Industrial Internacional Uniforme - CIIU (Revisión 3) y las divisiones 55 y 56 de la Sección I de la CIIU (Revisión 4).

Aunque, como hemos mencionado, la SUNAT lo ha traducido en "restaurantes y hoteles", al hacer tan engorrosa la norma, el contribuyente que quiera acceder a ese deducible no solo va a tener que exigir el comprobante de pago, si no verificar que la actividad económica registrada en el Registro Único de Contribuyentes (RUC) corresponda al CIIU deducible.

- La deducción es solo con comprobante de pago electrónico (Tabla 2.2).

El porcentaje a deducir están insignificante que no resulta un incentivo muy significativo para exigir comprobante de pago.

Tabla 2.2 Acreditación - Sustentación de Gastos en Restaurantes y Hoteles para Deducción Adicional de 3 UIT

\begin{tabular}{|c|c|c|}
\hline Vigencia & Regla Aplicable & Tipo de Comprobante de Pago \\
\hline $\begin{array}{l}\text { A partir } \\
\text { del } \\
01.01 .2019\end{array}$ & Regla General & $\begin{array}{l}\text { - } \text { Boleta de Venta Electrónica. } \\
\text {. Ticket POS } \\
\text {. Ticket monedero electrónico } \\
\text { Nota de débito y crédito } \\
\text { electrónicas. }\end{array}$ \\
\hline
\end{tabular}




\begin{tabular}{|l|l|l|}
\hline Regla de Excepción: Cuando el & \\
emisor no pueda emitir & noleta de venta, nota de \\
electrónicamente por causas no & $\begin{array}{l}\text { Bédito y nota de débito } \\
\text { imputables a él o cuando el } \\
\text { punto de emisión se encuentre } \\
\text { ubicado en una zona geográfica } \\
\text { de baja o nula conectividad a } \\
\text { internet. }\end{array}$ & $\begin{array}{l}\text { empresos y/o importados por } \\
\text { imprentas autorizadas }\end{array}$ \\
\hline
\end{tabular}

\subsection{Decreto Legislativo $N^{\circ}$ 1269: Crea el Régimen MYPE Tributario}

La Micro y Pequeña Empresa (MYPE) “es la unidad económica constituida por una persona natural o jurídica, bajo cualquier forma de organización o gestión empresarial contemplada en la legislación vigente, que tiene como objeto desarrollar actividades de extracción, transformación, producción, comercialización de bienes o prestación de servicios" (SUNAT).

\subsubsection{Las MYPE en el Perú}

El Perú, al igual que la mayoría de los países latinoamericanos, se caracteriza por ser una economía subdesarrollada donde el mercado productivo se da por empresas de baja gama, sin gran desarrollo industrial. Según Navarrete (2014):

Las empresas de reducida dimensión se caracterizan por tener estructuras sencillas de organización, mantener la identidad entre propiedad y gestión y contar con la presencia física y directa del empresario, características que se presentan como aliadas para la "informalidad" que se concreta en la ausencia de burocracia en las relaciones de vida empresarial, materializándose un "enanismo", por la evasión tributaria, escasas perspectivas de desarrollo para las empresas, y empleo de baja calidad. 
Esta informalidad, predominante en Latinoamérica, y en especial en nuestro país, trajo consigo la necesidad que el Estado intervenga al presentarse como una de las causas de la pobreza en el país, porque con la evasión tributaria el fisco no encuentra un crecimiento preponderante. Las consecuencias sociales que esto genera, si no se adoptan medidas de promoción para sujetos económicos de gama baja, afectan no solo la economía del estado sino más bien en la economía familiar y personal de cada ciudadano.

Claro está que la intención del empresario es competir en el mercado con cierto grado de ventaja en la reducción de costos, pero su finalidad no justifica la ilegalidad de la que se encuentra investida.

Dada la competitividad requerida, el micro y pequeño empresario buscará obtener la mayor cantidad de rentabilidad posible, presentándose la informalidad como su principal aliado, al ser que se evaden los altos costos en comparación con sus ingresos. Por eso, la misión del Estado en un principio, es promover su formalización (págs. 15-16).

Luna (2016) añade:

Que la alta informalidad afecta al Estado, pues no percibe los impuestos que su actividad económica genera, y revierte hacia las pequeñas empresas sin posibilidades de financiamiento en el sistema bancario. Esto implica que estas no pueden incorporarse a cadenas productivas de empresas formales.

\subsubsection{Características del régimen tributario creado}

El Régimen MYPE Tributario del Impuesto a la Renta (Decreto Legislativo $\left.\mathrm{N}^{\circ} 1269,2016\right)$ tiene entre sus principales características:

a. Comprende a Personas naturales y jurídicas, sucesiones indivisas y sociedades conyugales, las asociaciones de hecho de profesionales y similares que obtengan rentas de tercera categoría, 
domiciliadas en el país cuyos ingresos netos no superen las 1700 Unidades Impositivas Tributarias en el ejercicio gravable.

b. Pueden acogerse:

- De iniciar actividades, podrá acogerse con la declaración jurada mensual del mes de inicio de actividades, efectuada dentro de la fecha de su vencimiento.

- Si proviene del Nuevo RUS, podrá acogerse en cualquier mes del ejercicio gravable, mediante la presentación de la declaración jurada que corresponda.

- Si proviene del RER, podrá acogerse en cualquier mes del ejercicio gravable, mediante la presentación de la declaración jurada que corresponda.

- Si proviene del Régimen General, podrá afectarse con la declaración del mes de enero del ejercicio gravable siguiente.

No es un régimen dirigido solo a nuevos contribuyentes.

c. Además, por el año 2017, la SUNAT incorporo de oficio a los contribuyentes que al 31 de diciembre 2016 hubieren estado tributando en el Régimen General y cuyos ingresos netos del ejercicio 2016 no superaron las 1,700 Unidades Impositivas Tributarias, salvo que por el período de enero de 2017 se hayan acogido al Nuevo RUS o RER, con la declaración correspondiente al mes de enero del 2017, sin perjuicio que la SUNAT pueda en virtud de su facultad de fiscalización incorporar a estos sujetos en el Régimen General de corresponder.

Una de las finalidades del "Nuevo" Régimen tributario era formalizar los contribuyentes, pero fue dirigido principalmente a contribuyentes formalizados, generando un forado en el presupuesto fiscal.

\subsubsection{Factores no considerados en la creación de Régimen MYPE Tributario}

No se ha considerado a la hora de formular este nuevo régimen particularidades de las empresas que conforman el sector MYPE, por 
ejemplo, que este sector está compuesto por lo general por empresas familiares que tiene dos (2) destinos:

a. Que se mantenga en el tiempo con su ingreso promedio, dirigido a un mercado local. Por ejemplo, un negocio en el que el local comercial es la casa habitación donde sólo atienden los miembros de la familia (bodegas, panaderías, etc.)

b. Que crece, y pasa de la casa habitación a un local diferente, que requiere contratar personal que no es de su familia.

El primero, requiere un régimen tributario sencillo, con carga tributaria moderada a baja, que le permita continuar con su negocio y su auto sostenibilidad económica. El no contar con este negocio lo llevaría a incrementar el número de desempleados y por ende una carga para el estado. A este tipo de negocios, debe estar dirigido el Nuevo RUS, que cuenta con incentivos como el Seguro Integrado de Salud - SIS Emprendedor.

El segundo, por otro lado, requiere también de un régimen tributario sencillo, con carga tributaria moderada a baja, pero que le permita crecer, requiere de medidas que le permitan contar con fondos para invertir y crecer. El estado debe evaluar que este tipo de empresas más que pagar impuestos va a generar puestos de trabajo, y mover la economía con las transacciones con otros proveedores.

En el Impuesto a la Renta se debe tener claro que el "Único Régimen" empresarial es el Régimen General del Impuesto a la Renta, pero son tantas las formalidades vinculadas a este régimen que implican costos para los contribuyentes.

Si la norma te lo permitía, te acogías a otros regímenes de renta definitivos evaluando: monto de ingresos (RUS), por actividad (Agrario), por monto y actividad (RER), por ubicación geográfica (Amazonia).

El Régimen MYPE Tributario considera el volumen de ventas, pero por ejemplo no ha considerado el margen de ganancia por tipo de actividades, siendo que los ingresos netos de dos (2) actividades diferentes pueden ser iguales, pero los costos que asume la empresa no es la misma. El nuevo 
régimen Tributario debió dirigirse a los contribuyentes que no podían acogerse a los otros regímenes, por ejemplo los de actividad empresarial construcción, pero que el volumen de ingresos el costo de la formalidad (por ejemplo, requiere contar con un contador) es mayor a los resultados netos.

\subsection{Decreto Legislativo $\mathbf{N}^{\circ}$ 1270: Modifica el Régimen Único Simplificado}

Con la entrada en vigencia de este decreto legislativo, se redujo a dos (2) las categorías vigentes del Nuevo RUS (Tabla 2.3).

De esta manera, quienes tengan ventas hasta $S / 5,000$, pagarán una cuota mensual de S/ 20; mientras que quienes tengan ingresos de S/ 8,000 abonarán S/ 50 de cuota mensual. Lo mismo para las adquisiciones. El límite de ingresos o adquisiciones para la permanencia en el Régimen es de S/96,000 anuales.

Los sujetos que se acojan al nuevo RUS "y no se ubiquen en categoría alguna, se encontrarán comprendidos en la categoría 2 hasta el mes en que comuniquen la que le corresponde, inclusive".

Tabla 2.3 Tabla de categorías de Nuevo RUS vigente (2017)

\begin{tabular}{|c|c|c|c|}
\hline \multirow{4}{*}{ CATEGORIAS } & \multicolumn{3}{|c|}{ PARAMETROS } \\
\cline { 2 - 4 } & Total Ingresos & $\begin{array}{c}\text { Total } \\
\text { Brutos } \\
\text { Mensuales } \\
\text { (Hasta S/ })\end{array}$ & $\begin{array}{c}\text { Cuota } \\
\text { Mensuisiciones } \\
\text { Mensual } \\
\text { (Hasta S/ ) }\end{array}$ \\
\hline 1 & 5,000 & 5,000 & 20 \\
\hline 2 & 8,000 & 8,000 & 50 \\
\hline
\end{tabular}

Elaboración propia.

Fuente: SUNAT

El proceso modificatorio del régimen tributario Nuevo RUS, descrito en el punto 1.3 de este trabajo de investigación, ha sido involutivo, siendo que las tabla de 
categorías vigente (Tabla 2.3) se asemeja mucho a la creada con Decreto Legislativo $\mathrm{N}^{\circ} 777^{4}$ (Tabla 2.4).

Tabla 2.4 Tabla de categorías de RUS - Decreto Legislativo $\mathbf{N}^{\circ} 777$.

\begin{tabular}{|c|c|c|c|c|}
\hline Categorías & $\begin{array}{c}\text { Monto de } \\
\text { Ventas o } \\
\text { Servicios } \\
\text { Mensuales } \\
\text { (Hasta S/.) }\end{array}$ & $\begin{array}{c}\text { Impuesto } \\
\text { Bruto } \\
\text { (S/.) }\end{array}$ & $\begin{array}{c}\text { Crédito } \\
\text { Máximo } \\
\text { Deducible } \\
\text { (Hasta S/.) }\end{array}$ & $\begin{array}{c}\text { Cuota } \\
\text { Mensual } \\
\text { (S/.) }\end{array}$ \\
\hline $\mathrm{A}$ & 1,500 & 50 & 40 & 10 \\
\hline B & 3,200 & 180 & 145 & 35 \\
\hline $\mathrm{C}$ & 5,000 & 400 & 320 & 80 \\
\hline $\mathrm{D}$ & 6,600 & 700 & 550 & 150 \\
\hline $\mathrm{E}$ & 8,400 & 1,000 & 780 & 220 \\
\hline
\end{tabular}

La falta de criterio técnico para la modificación de este régimen tributario, durante la última reforma, es un reflejo de la idea del Poder Ejecutivo en ese momento, eliminar este régimen.

Shiguiyama (2017), cuando era jefe de la SUNAT, en entrevista brindada a Gestión, comento que se encontraba en conversaciones con el MEF a fin de eliminar el Nuevo RUS, expresando que esta era una posición institucional "nosotros [SUNAT] creemos que el RUS ya cumplió su ciclo". Añadió "Lo que nosotros planteamos es pensar en un modelo que sea realmente simple, y eso puede significar reinventar todo esto. Creo que es momento de pensar en cómo hacemos para que el contribuyente tenga beneficios para ser formal".

Por ejemplo - prosiguió - las personas naturales no tienen ningún incentivo para pedir su boleta o comprobante de pago o en el caso de RUS, que son alrededor de 400,000 empresas pequeñas, tampoco cuentan con incentivos para pedir su factura de compra. 
Puntualizado que "es necesario, entonces, que todos tengan incentivos positivos, (ya que) no solamente la fiscalización va resolver el problema.

Lo que no entendemos, es como ¿eliminar categorías de un régimen simplificando? y ¿obligar al contribuyente a acogerse una régimen con mayores obligaciones formales? Podría ser considerado un "incentivo positivo".

\subsection{Efectos en la Recaudación de La Reforma Tributaria}

\subsubsection{Caída en la Recaudación del Impuesto a la Renta Empresarial}

De la información disponible en la página web de la SUNAT, al cierre del ejercicio 2017 se puede ver una caída en la recaudación de aproximadamente 1,000 millones en el Impuesto a la Renta, considerando que aproximadamente 995 millones corresponden a lo recaudado por el Régimen de Repatriación de Capitales, se ha superado ampliamente el costo proyectado por el MEF (Tabla 2.5). 
Tabla 2.5 Ingresos Tributarios del Gobierno Central - En millones de soles y variación real (\%)

\begin{tabular}{|c|c|c|c|c|c|c|}
\hline & \multicolumn{2}{|c|}{ Diciembre } & \multirow{2}{*}{ Var\% Real } & \multicolumn{2}{|c|}{ Acumulado a Diciembre } & \multirow{2}{*}{ Var\% Real } \\
\hline & $2016(A)$ & 2017 (B) & & $2016(A)$ & 2017 (B) & \\
\hline Ingresos Gobierno Central (Bruto) & 9,687 & 10,536 & 7.3 & 105,731 & 107,914 & -0.7 \\
\hline Ingresos Gobierno Central (Neto) & 8,543 & 9,750 & 12.6 & 89,375 & 90,706 & -1.3 \\
\hline Impuesto a la Renta & 3,648 & 3,919 & 6.0 & 37,214 & 36,755 & -4.0 \\
\hline Tercera Categoria y RMT & 1,386 & 1,524 & 8.4 & 16,496 & 16,403 & -3.3 \\
\hline Tercera Categoría & 1,386 & 1,416 & 0.7 & 16,496 & 15,505 & -8.6 \\
\hline Régimen MYPE Tributario & 0 & 108 & - & 0 & 898 & \\
\hline Regularización & 131 & 1,164 & 777.4 & 3,805 & 4,884 & 24.0 \\
\hline Quinta Categoría & 628 & 637 & 0.0 & 8,248 & 8,444 & -0.5 \\
\hline No domiciliados & 1,232 & 263 & -78.9 & 5,205 & 3,462 & -35.1 \\
\hline Resto Rentas & 271 & 332 & 20.9 & 3,460 & 3,562 & 0.1 \\
\hline A la Producción y al Consumo & 5,095 & 5,450 & 5.5 & 58,767 & 61,132 & 1.2 \\
\hline Impuesto General a las Ventas & 4,544 & 4,843 & 5.2 & 52,692 & 54,643 & 0.9 \\
\hline Interno & 2,639 & 2,848 & 6.5 & 31,040 & 32,114 & 0.6 \\
\hline Importaciones & 1,905 & 1,994 & 3.3 & 21,652 & 22,529 & 1.2 \\
\hline Impuesto Selectivo al Consumo & 537 & 590 & 8.4 & 5,902 & 6,315 & 4.1 \\
\hline Interno & 352 & 339 & -4.9 & 3,929 & 3,727 & -7.7 \\
\hline Importaciones & 185 & 251 & 33.9 & 1,973 & 2,588 & 27.7 \\
\hline Otros a la Producción y al Consumo & 15 & 17 & 9.3 & 173 & 174 & -1.7 \\
\hline A la importación & 139 & 125 & -11.3 & 1,606 & 1,448 & -12.3 \\
\hline Otros Ingresos & 805 & 1,043 & 27.9 & 8,145 & 8,579 & 2.5 \\
\hline Fraccionamientos & 91 & 92 & 0.4 & 1,068 & 1,109 & 1.0 \\
\hline Casinos y Tragamonedas & 24 & 23 & -6.4 & 298 & 297 & -3.0 \\
\hline Multas & 42 & 133 & 211.1 & 485 & 513 & 2.9 \\
\hline ITAN & 436 & 507 & 14.8 & 4,300 & 4,585 & 3.8 \\
\hline Otros & 212 & 287 & 33.7 & 1,994 & 2,075 & 1.2 \\
\hline Devoluciones & $-1,144$ & -786 & -32.2 & $-16,356$ & $-17,209$ & 2.3 \\
\hline \multicolumn{7}{|l|}{ Memo } \\
\hline Tributos Internos & 7,447 & 8,151 & 8.0 & 80,347 & 81,224 & -1.7 \\
\hline Tributos Aduaneros & 2,240 & 2,385 & 5.1 & 25,384 & 26,690 & 2.3 \\
\hline
\end{tabular}

Fuente: SUNAT

Tabla 2.6 Recaudación de las Rentas Empresariales 2017 (Proyectado versus Ejecutado)

\begin{tabular}{|c|c|c|c|c|c|}
\hline \multirow{2}{*}{$\begin{array}{l}\text { PARTIDA } \\
\text { PRESUPUESTA } \\
\text { RECURSOS } \\
\text { ORDINARIOS } \\
\end{array}$} & \multicolumn{3}{|c|}{ INGRESOS PRESUPUESTO PUBLICO 2017} & \multirow{2}{*}{$\begin{array}{c}\text { INGRESO } \\
\text { EJECUTADO }\end{array}$} & \multirow{2}{*}{$\begin{array}{c}\text { DIFERENCIA } \\
\text { (DEFICIT) }\end{array}$} \\
\hline & Inicial & Modificaciones & Final & & \\
\hline Tercera Categoría & $15,443,091,278.00$ & $-1,661,000,000.00$ & $13,782,091,278.00$ & $13,155,850,499.11$ & $-626,240,778.89$ \\
\hline $\begin{array}{l}\text { Régimen Especial de Renta } \\
\text { (RER) }\end{array}$ & $344,049,792.00$ & $-183,000,000.00$ & $161,049,792.00$ & $322,856,914.41$ & $161,807,122.41$ \\
\hline Régimen para la Amazonía & $30,425,123.00$ & 0.00 & $30,425,123.00$ & $2,933,116.30$ & $-27,492,006.70$ \\
\hline Régimen Agrario & $119,509,472.00$ & 0.00 & $119,509,472.00$ & $177,926,790.83$ & $58,417,318.83$ \\
\hline Régimen de Frontera & $9,184.00$ & 0.00 & $9,184.00$ & $6,380.98$ & $-2,803.02$ \\
\hline Régimen MYPE Tributario & 0.00 & $2,609,000,000.00$ & $2,609,000,000.00$ & $904,135,143.45$ & $-1,704,864,856.55$ \\
\hline $\begin{array}{l}\text { Nuevo Régimen Único } \\
\text { Simplificado (RUS) }\end{array}$ & $201,180,574.00$ & $-42,000,000.00$ & $159,180,574.00$ & $140,325,504.31$ & $-18,855,069.69$ \\
\hline SUBTOTAL & $16,138,265,423.00$ & $723,000,000.00$ & $16,861,265,423.00$ & $14,704,034,349.39$ & $-2,157,231,073.61$ \\
\hline
\end{tabular}

Elaboración Propia.

Fuente: Programación y Ejecución Presupuestaria del Presupuesto de Ingresos (PEPI) Ejercicio 2017 SUNAT (500101). 
No obstante, con excepción del flujo de ingresos extraordinarios cuyo impacto se dio en la renta de no domiciliados durante el ejercicio 2017, los demás factores han tenido impacto en contribuyentes cuya aportación a la recaudación no puede justificar la importante caída en la recaudación total. Pero para evaluar el efecto real en la caja fiscal, se tienen que analizar los resultados del Presupuesto Público del ejercicio, proyectado por el MEF, comparados con lo realmente ejecutado (Tabla 2.6).

De la proyección inicial de los ingresos por impuestos, la proyección positiva del MEF por 723 millones (modificaciones), tiene revés de -2,157 millones. En los términos del Presupuesto Público los factores descritos por la SUNAT le costaron a la caja fiscal 2,880 millones, duplicando el monto que había estimado el MEF, y expuesto en las exposiciones de motivo de la reforma tributaria.

\subsubsection{Variación de la Base Tributaria de contribuyentes que generan Renta Empresarial}

La SUNAT pasó de oficio a contribuyentes formales, acogidos a uno de los otros regímenes tributarios vigentes, a este nuevo régimen, afectando la recaudación tributaria al reducirla las obligaciones tributarias (tasa del pago a cuenta del impuesto a la renta a pagar). De la información disponible en su página web aproximadamente el $72.88 \%$ de los contribuyentes del Régimen MYPE Tributario representan la caída de la base tributaria del Régimen General de Tercera Categoría (Tabla 2.7).

El incremento de la base tributaria, o cantidad de contribuyentes del 9.2\%, que incluyen los de Régimen MYPE Tributario, corresponde al crecimiento natural que se da cada año, durante el 2016 (Tabla 2.8), antes de la existencia de este régimen se incrementó la base tributaria en 101.9 mil contribuyentes o 5.2\%). Siendo que tampoco se llega al monto total de beneficiados con este nuevo régimen tributario proyectado por el gobierno (aprox. 700 mil contribuyentes). 
Tabla 2.7 Contribuyentes Inscritos según Régimen Tributario, Variación 2016 - 2017 (En miles)

\begin{tabular}{|c|c|c|c|c|}
\hline Concepto & $\begin{array}{r}\text { Dic. } \\
2016\end{array}$ & $\begin{array}{r}\text { Dic. } \\
2017\end{array}$ & Variaci & $\%$ \\
\hline I. Contribuyentes con RUC & $2,080.0$ & $2,271.0$ & 191.0 & $9.2 \%$ \\
\hline Principales Contribuyentes & 12.8 & 14.7 & 19 & $15.1 \%$ \\
\hline Medianos y Pequeños Contribuyentes & $2,067.2$ & 2,2563 & 189.1 & $9.1 \%$ \\
\hline Rëgimen General & 6041 & 245.0 & 359.0 & $-59.4 \%$ \\
\hline Tercera Categoria & 5952 & 235.6 & -359.6 & $-60.4 \%$ \\
\hline Otras rentas de Tercera Categoria & 8.9 & 9.4 & 0.5 & $5.9 \%$ \\
\hline Reggmen Especial de Renta & 373.8 & 374.5 & 0.7 & $0.2 \%$ \\
\hline Rejgimen Uñico Simplificado & 1,0893 & $1,143.4$ & 54.1 & $5.0 \%$ \\
\hline Rẻgimen MYPE Tributario & 0.0 & 493.4 & 493.4 & $10 \overline{0} 0 \%$ \\
\hline
\end{tabular}

Elaboración Propia.

Fuente: SUNAT - Intendencia Nacional de Estudios Económicos y Estadística

Tabla 2.8 Contribuyentes Inscritos según Régimen Tributario, Variación 2015 - 2016 (En miles)

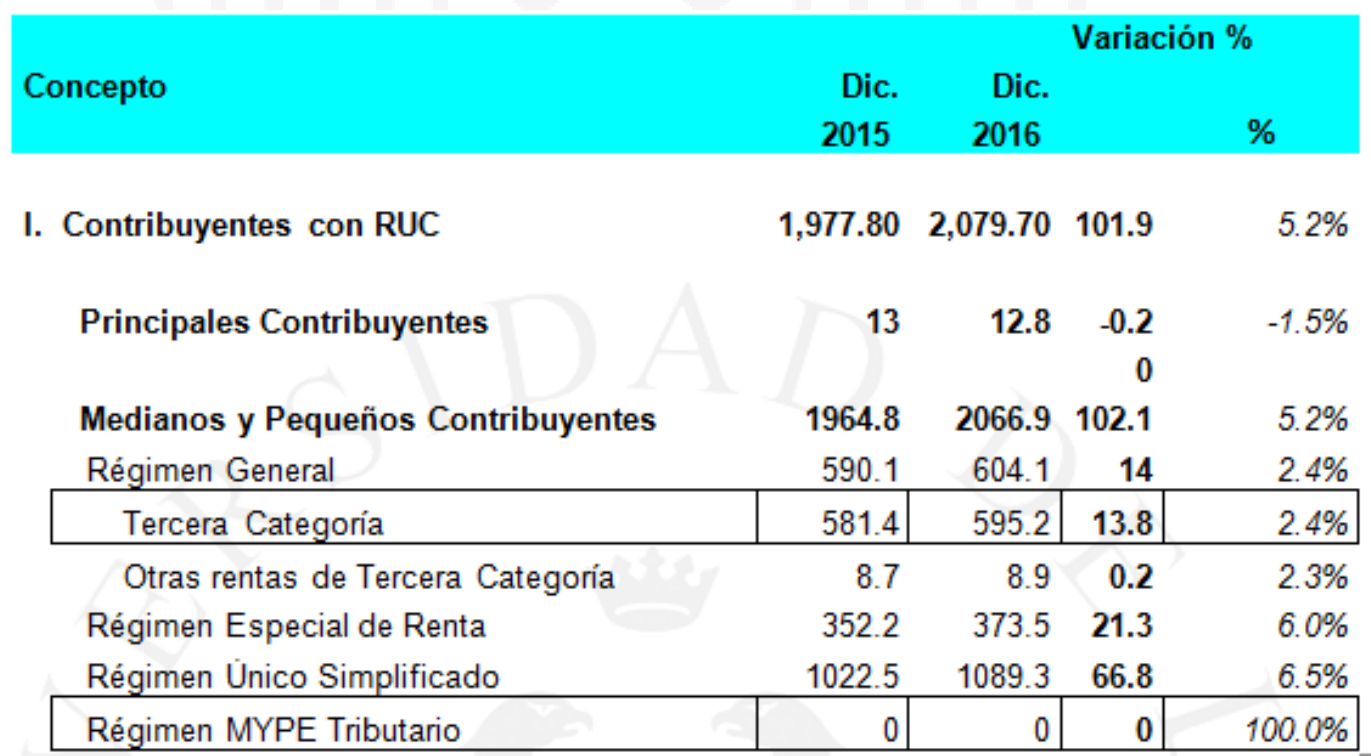

Elaboración Propia.

Fuente: SUNAT - Intendencia Nacional de Estudios Económicos y Estadística

Aunque en los documentos citados previamente no se deja constancia de que la intención del gobierno fuera la de la ampliación de la base tributaria, no se puede hablar de "incentivar la formalización” sin entender tácitamente 
que es por el cumplimiento de "formalidades" como el trámite ante SUNAT del Registro Único de Contribuyentes (RUC).

Esta norma no ha cumplido con la parte de incentivar a la formalidad, y por ende la ampliación de la Base Tributaria, aunque si estaría incentivando a las empresas a mantenerse en la formalidad.

\subsection{Conclusiones preliminares}

De lo expuesto en el presente capitulo, podemos concluir que la Reforma Tributaria se caracteriza por una falta de criterio técnico y análisis de la realidad nacional. Esta se ha dado en un contexto "ideal".

De la exposición de motivos, considerando que uno de los principales fines era luchar contra la informalidad, no se puede verificar que cuente con un estudio o investigación del mercado informal que se busca erradicar. Asimismo, las medidas de esta reforma tributaria, no apunta a incrementar la base tributaria, si no a tratar de simplificar el proceso de control y fiscalización de la Administración Tributaria con el incremento de obligaciones para los contribuyentes y terceros.

La Reforma Tributaria se centró en cumplir las promesas de campaña alineadas a lo que la oposición en el congreso les dejo cumplir. Ya en la exposición de motivos de algunos Decretos Legislativos, el MEF trata de justificar los cambios del Congreso en la delegación de facultades. Todo el proceso de Reforma Tributaria ha sido una pugna de poderes entre el Poder Ejecutivo y la mayoría opositora del Congreso (Poder Legislativo) y el resultado ha sido la creación de un nuevo Régimen Tributario que ha incentivado la informalidad, al generar más costo para los contribuyentes, sin que a la fecha se pueda medir cuantos nuevos informales tenemos.

Si comparamos los regímenes tributarios que han quedado después de la reforma tributaria analizada (Tabla 2.9), podemos concluir fácilmente que la simplicidad que exige el control del Nuevo RUS permite a la Administración Tributaria avocar sus recursos al control de otros contribuyentes de mayor importancia fiscal. 
Finalmente, en nuestra opinión el error del Poder Ejecutivo fue tratar de vender el Régimen MYPE como una herramienta de reducción de la informalidad o simplificación. Sin que esto desmerezca la necesidad de un régimen con características similares, somos de la opinión de que el sistema tributario necesitaba contar con un régimen simplificado para contribuyentes que tienen la necesidad de emitir comprobantes de pago que pueden ser sustentados como costo o gasto, y que por la actividad (Tabla 2.9 Restricción por tipo de actividad) que desarrolla se encuentran excluidos del Régimen Especial del Impuesto a la Renta (RER).

Por actividad económica, para una persona natural que inicia actividades, tenemos dos (2) grupos: sin restricción, un régimen simplificado y una general; y con restricción, dos regímenes simplificados, uno que emite comprobantes de pago que sustentan costo o gasto, y otro que no emite este tipo de comprobantes. Muchas opciones para un contribuyente que inicia actividades, se hace necesario contar con asesoría (evaluar pros y contras). Asesoría que no va a encontrar en la SUNAT; puesto que esta se limita a orientar. 
Tabla 2.9 Cuadro Comparativo de los Regímenes Tributarios vigentes después de la Reforma Tributaria

\begin{tabular}{|c|c|c|c|c|}
\hline Conceptos & $\begin{array}{l}\text { Nuevo Régimen } \\
\text { Único } \\
\text { Simplificado } \\
\text { (NRUS) }\end{array}$ & $\begin{array}{c}\text { Régimen } \\
\text { Especial de } \\
\text { Impuesto a la } \\
\text { Renta (RER) }\end{array}$ & $\begin{array}{c}\text { Régimen MYPE } \\
\text { Tributario (RMT) }\end{array}$ & $\begin{array}{c}\text { Régimen } \\
\text { General (RG) }\end{array}$ \\
\hline Persona Natural & Sí & \multirow{2}{*}{\multicolumn{3}{|c|}{ Sí }} \\
\hline Persona Jurídica & NO & & & \\
\hline $\begin{array}{l}\text { Límite de } \\
\text { ingresos }\end{array}$ & \multirow[t]{2}{*}{$\begin{array}{c}\text { Hasta S/. 96,000 } \\
\text { anuales u S/ 8,000 } \\
\text { mensuales. }\end{array}$} & \multirow[t]{2}{*}{$\begin{array}{c}\text { Hasta } S / .525,000 \\
\text { anuales. }\end{array}$} & $\begin{array}{l}\text { Ingresos netos que no } \\
\text { superen } 1700 \text { UIT en el } \\
\text { ejercicio gravable } \\
\text { (proyectado o del } \\
\text { ejercicio anterior). }\end{array}$ & \multirow[t]{2}{*}{ Sin límite } \\
\hline $\begin{array}{l}\text { Límite de } \\
\text { compras }\end{array}$ & & & Sin límite & \\
\hline $\begin{array}{l}\text { Comprobantes } \\
\text { que pueden } \\
\text { emitir }\end{array}$ & $\begin{array}{l}\text { Boleta de venta y } \\
\text { tickets que no dan } \\
\text { derecho a crédito } \\
\text { fiscal, gasto o } \\
\text { costo. }\end{array}$ & $\begin{array}{l}\text { Factura, boleta y } \\
\text { todos los demás } \\
\text { permitidos. }\end{array}$ & $\begin{array}{l}\text { Factura, boleta y todos } \\
\text { los demás permitidos. }\end{array}$ & $\begin{array}{c}\text { Factura, boleta y } \\
\text { todos los demás } \\
\text { permitidos. }\end{array}$ \\
\hline DJ anual - Renta & \multicolumn{2}{|c|}{ NO } & \multicolumn{2}{|l|}{ Sí } \\
\hline \multirow[t]{2}{*}{$\begin{array}{l}\text { Pago de tributos } \\
\text { mensuales }\end{array}$} & $\begin{array}{l}\text { Pago mínimo S/ } \\
20 \text { y máximo } \\
\text { S/50, de acuerdo a } \\
\text { una tabla de } \\
\text { ingresos y/o } \\
\text { compras por } \\
\text { categoría. }\end{array}$ & $\begin{array}{l}\text { Renta: Cuota de } \\
1.5 \% \text { de ingresos } \\
\text { netos mensuales } \\
\text { (Cancelatorio). }\end{array}$ & $\begin{array}{l}\text { Renta: Si no superan las } \\
300 \text { UIT de ingresos } \\
\text { netos anuales: pagarán } \\
\text { el } 1 \% \text { de los ingresos } \\
\text { netos obtenidos en el } \\
\text { mes. Si en cualquier } \\
\text { mes superan las } 300 \\
\text { UIT de ingresos netos } \\
\text { anuales pagarán } 1.5 \% \text { o } \\
\text { coeficiente. }\end{array}$ & $\begin{array}{c}\text { Renta: Pago a } \\
\text { cuenta mensual. } \\
\text { El que resulte } \\
\text { como coeficiente } \\
\text { o el } 1.5 \% \text { según } \\
\text { la Ley del } \\
\text { Impuesto a la } \\
\text { Renta. }\end{array}$ \\
\hline & $\begin{array}{l}\text { El IGV está } \\
\text { incluido en la } \\
\text { única cuota que } \\
\text { se paga en éste } \\
\text { régimen. }\end{array}$ & $\begin{array}{l}\text { IGV: } 18 \% \\
\text { (incluye el } \\
\text { impuesto de } \\
\text { promoción } \\
\text { municipal). }\end{array}$ & $\begin{array}{c}\text { IGV: } 18 \% \text { (incluye el } \\
\text { impuesto de promoción } \\
\text { municipal). }\end{array}$ & $\begin{array}{l}\text { IGV: } 18 \% \\
\text { (incluye el } \\
\text { impuesto de } \\
\text { promoción } \\
\text { municipal). }\end{array}$ \\
\hline $\begin{array}{l}\text { Restricción por } \\
\text { tipo de actividad }\end{array}$ & \multicolumn{2}{|c|}{ SI TIENE } & \multicolumn{2}{|c|}{ NO TIENE } \\
\hline Trabajadores & Sin límite & 10 por turno & \multirow{2}{*}{\multicolumn{2}{|c|}{ Sin límite }} \\
\hline $\begin{array}{l}\text { Valor de activos } \\
\text { fijos }\end{array}$ & $\mathrm{S} / 70,000$ & S/ 126,000 & & \\
\hline $\begin{array}{l}\text { Posibilidad de } \\
\text { deducir gastos }\end{array}$ & \multirow{2}{*}{\multicolumn{2}{|c|}{ NO TIENE }} & \multirow{2}{*}{\multicolumn{2}{|c|}{ SI TIENE }} \\
\hline $\begin{array}{c}\text { Pago del } \\
\text { Impuesto Anual } \\
\text { en función a la } \\
\text { utilidad }\end{array}$ & & & & \\
\hline
\end{tabular}

Fuente: Página web de SUNAT. UIT: Unidades Impositivas Tributarias. 


\section{CAPÍTULO III: REGIMENES SIMPLIFICADOS EN LA LEGISLACIÓN COMPARADA}

Los regímenes tributarios a analizar en este capítulo tienen en común con el Nuevo RUS que: están dirigidos a personas naturales con negocio (trabajadores independientes) y buscan ser regímenes simples para reducir la informalidad.

\subsection{La Situación de América Latina}

Para Solórzano T. (2011) el alto índice de evasión tributaria e informalidad en América Latina se da principalmente por la: "1) Inexistencia de conciencia tributaria de la población; 2) Complejidad y limitaciones de la legislación tributaria; [e] 3) Ineficiencia de la Administración tributaria” (pág. 12)

Añade:

1. - [La] Inexistencia de conciencia [cultura] tributaria de la población. [Aunque] todos los ciudadanos tenemos la obligación de pagar voluntariamente y puntualmente nuestras obligaciones para el sostenimiento de los estados, partimos de una primera concepción de que a nadie le agrada pagar sus impuestos (...) conllevándonos a una falta de conciencia tributaria y por ende a una falta de conciencia social, complementando esta falta de conciencia tributaria esta la resistencia que asume la población por la percepción que los individuos hacen por la imagen que dan los gobiernos en la forma como estos administran los recursos. (...)

2.- Complejidad y limitaciones de la legislación tributaria. La normatividad tributaria en estos países son muy complejas y confusas, (...)

3.- Ineficiencia de la Administración Tributaria. Este concepto es muy importante ya que viene ha [sic] ser la piedra angular para combatir la evasión tributaria y un pilar para el desarrollo de los países. Para ello la 
Administración tributaria debe combatir al evasor que viene ha $[\mathrm{sic}]$ ser un individuo racional que actúa con el fin de obtener lucro produciendo al máximo sus rentas, acrecentando esta evasión en cuanto sea menor la probabilidad de ser detectado $y$ en forma competente por la Administración.

La imagen de riesgo es fundamental en los países, percibiéndose la presencia de la Administración Tributaria, en donde la probabilidad sería alta de un contribuyente evasor sea detectado, sumiendo cada uno de ellos el costo de evadir. De lo indicado es necesario contar con una administración tributaria eficiente y efectiva dentro de un marco jurídico claro y correlativo. (págs. 12-13)

Al respecto, durante el debate en la cámara en la cámara de Senadores de Argentina, en la que se discutía la implementación de un Régimen simplificado para pequeños contribuyentes, régimen que analizaremos más adelante, el senador Aguirre L. (1998) argumenta su apoyo a la creación de dicho régimen precisando:

Voy a apoyar este proyecto porque, sin duda alguna, significa un acto de equidad fiscal y de conveniencia fiscal. ¿Por qué digo esto? Porque en las exposiciones precedentes (...) ha quedado muy en claro que debemos afrontar con realismo una situación respecto de la cual nadie duda.

Nos encontramos con una enorme masa de contribuyentes que no eran tales [informales]. Y no lo eran no porque hubiera mala fe o se desoyera la obligación tributaria que impone el Estado sino porque, prácticamente, estaban imposibilitados de cumplir de la manera que correspondía. Eso se debía, por un lado, a su falta de preparación y, (...), a que, (...) no disponían de los recursos necesarios para pagar el asesoramiento -siempre costosoque les permitiera pasar por encima de una verdadera maraña de normas $(\ldots)$

En cambio, con el sistema que se propone no habrá mayores dificultades para cumplir eficaz y lealmente las obligaciones tributarias. (...)

Con esta norma, habrá mucha gente que tendrá la tranquilidad de saber que, pagando una módica cuota, no estará al margen de la ley. Ello 
provocará no sólo el beneficio de esa gente, sino también el del propio Estado en su carácter de ente recaudador.

Si bien es cierto que con la aplicación de esta norma en algunos casos se tributará menos de lo que podría llegar a tributarse con un régimen general (...), lo real es que habrá una cantidad muy grande de gente que no tributaba y que no iba a tributar que ahora va a tratar de "blanquearse" en su posición frente al Estado.

Es decir, no sólo vamos a cumplir con mucha gente que quiere ingresar legalmente en una relación tributaria con el Estado, sino que este régimen le aportará al Estado un flujo sumamente importante de fondos.

Según Arias M. (2018), ex Superintendente de la SUNAT y actual de Presidente Ejecutivo del Banco de la Nación:

Los regímenes simplificados para pequeños contribuyentes (RTSP) existen en casi todos los países de América Latina, así como varias justificaciones para la existencia de tales regímenes, entre las cuales están el hecho de lograr:

a) Mayor formalidad: propiciar una mayor formalidad y la consiguiente ampliación de la base tributaria de contribuyentes.

b) Menor costo de cumplimiento: propiciar reducciones en los costos de cumplimiento tributario de un grupo de contribuyentes sobre quienes podría recaer en mayor magnitud.

c) Costo-eficiencia: reducir los costos de administrar el cumplimiento de obligaciones tributarias de un número grande de pequeños contribuyentes (de relativo poco interés fiscal).

d) Menor evasión: reducir el incumplimiento tributario originado por un grupo de contribuyentes formales que enfrentan elevados costos de cumplimiento tributario.

e) Mejor determinación: facilitar la determinación correcta de las obligaciones tributarias de ciertos contribuyentes.

El diseño del RTSP es crucial. Hay dos variables importantes en el diseño: el umbral de ingresos para pertenecer al RTSP y el diferencial de tasas 
entre el contribuyente del régimen general y el contribuyente del RTSP. Si el valor de estas dos variables es elevado, el riesgo de promover la atomización de contribuyentes y de desincentivar el crecimiento de la productividad es mayor.

\subsection{Argentina: Régimen Simplificado para Pequeños Contribuyentes}

El Régimen Simplificado para Pequeños Contribuyentes argentino fue creado con la Ley $\mathrm{N}^{\mathrm{o}} 24.997$ publicada el 6 de julio de 1998, conocido coloquialmente como el Monotributo, "unifica el componente impositivo -IVA y Ganancias- y el componente previsional -aportes jubilatorios y obra social- en una única cuota mensual, haciendo más simple y ágil cumplir con tus obligaciones. Se deben cumplir con determinados valores de parámetros como facturación anual, superficie de locales, energía eléctrica consumida y el monto de alquiler del local/es" (AFIP).

Este régimen considera pequeños contribuyentes a:

1) Las personas humanas que realicen venta de cosas muebles, locaciones, prestaciones de servicios y/o ejecuciones de obras, incluida la actividad primaria;

2) Las personas humanas integrantes de cooperativas de trabajo, en los términos y condiciones que se indican en el Título VI; y

3) Las sucesiones indivisas continuadoras de causantes adheridos al Régimen Simplificado para Pequeños Contribuyentes, hasta la finalización del mes en que se dicte la declaratoria de herederos, se declare la validez del testamento que verifique la misma finalidad o se cumpla un año dese el fallecimiento del causante, lo que suceda primero.

(Ley $\left.N^{\circ} 24.977\right)$

El pago único se puede hacer en 11 categorías por ingresos anuales: " $A$ " a la " $H$ " para los prestadores de servicios y de la " $A$ " a la " $K$ " para quienes vendan productos. 
Artículo $9^{\circ}$.- A la finalización de cada semestre calendario, el pequeño contribuyente deberá calcular los ingresos brutos acumulados, la energía eléctrica consumida y los alquileres devengados en los doce (12) meses inmediatos anteriores, así como la superficie afectada a la actividad en ese momento. Cuando dichos parámetros superen o sean inferiores a los límites de su categoría, quedará encuadrado en la categoría que le corresponda a partir del segundo mes inmediato siguiente al último mes del semestre respectivo.

Para efectuar la recategorización por semestre calendario (enero/junio y julio/diciembre) (2017).

Se puede pagar con transferencia electrónica, débito automático en cuenta o tarjeta de crédito, a través de cajero automático, entre otras opciones. Si el contribuyente realiza el pago con débito automático o tarjeta de crédito pueden acceder al beneficio de un reintegro por pago en termino: 12 periodos fiscales, recibe el 100\% de una cuota; de 6 a 11 periodos fiscales, recibe el 50\%. El reintegro se abona automáticamente los primeros meses del año siguiente a la cuenta desde donde se realizaron los pagos.

Artículo $11^{\circ}$.- (...) Autorízase al Poder Ejecutivo nacional a bonificar en una o más mensualidades - hasta un veinte por ciento (20\%) del impuesto integrado total a ingresar en un ejercicio anual, a aquellos pequeños contribuyentes que cumplan con una determinada modalidad de pago o que guarden estricto cumplimiento con sus obligaciones formales y materiales. (2017).

Simplicidad para el contribuyente:

- Las categorías se definen por parámetros sencillos: superficie utilizada para la actividad, energía eléctrica consumida anualmente, alquileres devengados anualmente, ingresos brutos anuales, tipo de actividad (servicio o venta de bienes).

- Pagar en plazo es la única obligación, y si se hace con medio electrónico se obtiene un reintegro. 
- Es predictible: la categoría, el monto de pago mensual, lo mantienes por 6 meses, siendo que de haber superado el límite de la categoría este afecta recién el semestre siguiente, cuando entre en vigencia el cambio de régimen. Simplicidad para la Administración:

- A partir del $1^{\circ}$ de abril del presente ejercicio, deberán emitir comprobantes de pago electrónicos a consumidores finales.

- Las categorías de este régimen se actualizan anualmente de manera automática por un índice económico externo: en la proporción de las dos (2) últimas variaciones del índice de movilidad de las prestaciones previsionales.

La Ley $\mathrm{N}^{\circ}$ 27.346, publicada el 27 de diciembre del 2016, establece como mes de a actualización de los límites máximos de cada categoría setiembre de cada año. La Ley $\mathrm{N}^{\circ} 27.430$, publicada el 27 de diciembre del 2017, la cambia a enero de cada año:

ARTÍCULO 161.- Sustitúyese el artículo 52 del anexo de la ley 24.977, sus modificaciones y complementarias, por el siguiente:

“ARTÍCULO 52.- Los montos máximos de facturación, los montos de alquileres devengados y los importes del impuesto integrado a ingresar, correspondientes a cada categoría de pequeño contribuyente, así como las cotizaciones previsionales y los importes consignados en el inciso c) del tercer párrafo del artículo $2^{\circ}$, en el inciso e) del segundo párrafo del artículo 31 y en el primer párrafo del artículo 32, se actualizarán anualmente en enero en la proporción de las dos (2) últimas variaciones del índice de movilidad de las prestaciones previsionales, previsto en el artículo 32 de la ley 24.241 y sus modificaciones y normas complementarias.

Las actualizaciones dispuestas precedentemente resultarán aplicables a partir de enero de cada año, debiendo considerarse los nuevos valores de los parámetros de ingresos brutos y alquileres devengados para la recategorización prevista en el primer párrafo del artículo $9^{\circ}$ correspondiente al segundo semestre calendario del año anterior." (Ley $\mathrm{N}^{\circ}$ 27.430, 2017) 
A fin de poder tener una idea monetaria de la carga tributaria ${ }^{5}$ que asumen $\operatorname{los}$ contribuyentes de este régimen en Argentina se calcula (Tabla 3.1) que en la categoría A, la más baja del régimen en la tabla de categorías vigentes a partir del 01 de enero del presente ejercicio ${ }^{6}$, el ingreso bruto promedio mensual es equivalente a más de un (1) sueldo mínimo argentino; y en la categoría $\mathrm{K}$, la más alta del régimen, el ingreso bruto promedio mensual es equivalente a casi trece (13) sueldos mínimos argentino. Elaborando un equivalente con el sueldo mínimo peruano (Tabla 3.2), usando el sueldo mínimo como factor de conversión, las 11 categorías en el Perú irían con ingreso bruto promedio mensual de S/ 947.34 en la categoría más baja (A) a S/. 11,841 en la categoría más alta (K), y cuotas mensuales de S/. 9.20 a S/ 639.45.

De la categorización argentina, entre categorías se nota un incremento en el porcentaje que equivale el monto a pagar del promedio mensual de los ingresos (más ingresos, más pagas). Siendo los más beneficiados los que generan menos ingresos mensuales.

Hay situaciones coyunturales en la economía Argentina que se tendrían que ajustar a la peruana. Asimismo, se tiene que tener en cuenta que en el Argentina la facturación electrónico opcional y obligación progresiva inicio en el 2005 (Resolución General AFIP N 1956/2005), mientras que en el Perú se inicia recién el 2010 (Resolución de Superintendencia N 188-2010/SUNAT). Aportes Obra Social, dado que el Nuevo RUS no tiene dichas cargas. 
Tabla 3.1 Ingreso bruto promedio mensual por categoría del Régimen Simplificado para Pequeños Contribuyentes - Monotributo Argentino expresado en cantidad de sueldos mínimos argentinos (11,300 ARS)

\begin{tabular}{|c|c|c|c|c|c|c|c|c|c|c|c|}
\hline \multirow[b]{2}{*}{ Categ. } & \multicolumn{2}{|c|}{ Ingresos Brutos } & \multirow[b]{2}{*}{ Actividad } & \multirow[b]{2}{*}{$\begin{array}{c}\text { Sup. } \\
\text { Afectada }\end{array}$} & \multirow[b]{2}{*}{$\begin{array}{l}\text { Energía } \\
\text { Eléctrica } \\
\text { Consumida } \\
\text { Anualmente }\end{array}$} & \multirow[b]{2}{*}{$\begin{array}{c}\text { Alquileres } \\
\text { Devengados } \\
\text { Anualmente }\end{array}$} & \multicolumn{2}{|c|}{ Impuesto Integrado } & \multicolumn{2}{|c|}{$\%$ de ingreso bruto mensual } & \multirow{2}{*}{$\begin{array}{c}\text { Ingreso } \\
\text { bruto } \\
\text { promedio } \\
\text { mensual } \\
\text { expresado } \\
\text { en } \\
\text { Cantidad } \\
\text { de Sueldos } \\
\text { Mínimos }\end{array}$} \\
\hline & $\begin{array}{c}12 \text { meses } \\
\text { acumulados }\end{array}$ & $\begin{array}{c}\text { Promedio } \\
\text { mensual }\end{array}$ & & & & & $\begin{array}{c}\text { Locaciones } \\
\text { y/o } \\
\text { Prestaciones } \\
\text { de Servicios }\end{array}$ & $\begin{array}{l}\text { Venta de } \\
\text { Cosas } \\
\text { Muebles }\end{array}$ & $\begin{array}{c}\text { Locaciones } \\
\text { y/o } \\
\text { Prestaciones } \\
\text { de Servicios }\end{array}$ & $\begin{array}{l}\text { Venta de } \\
\text { Cosas } \\
\text { Muebles }\end{array}$ & \\
\hline $\mathrm{A}$ & $138,127.99$ & $11,510.67$ & \multirow{8}{*}{$\begin{array}{c}\text { No } \\
\text { excluida }\end{array}$} & $30 \mathrm{~m} 2$ & $3330 \mathrm{Kw}$ & $51,798.00$ & 111.81 & 111.81 & $0.97 \%$ & $0.97 \%$ & 1.02 \\
\hline B & $207,191.98$ & $17,266.00$ & & $45 \mathrm{~m} 2$ & $5000 \mathrm{Kw}$ & $51,798.00$ & 215.42 & 215.42 & $1.25 \%$ & $1.25 \%$ & 1.53 \\
\hline $\mathrm{C}$ & $276,255.98$ & $23,021.33$ & & $60 \mathrm{~m} 2$ & $6700 \mathrm{Kw}$ & $103,595.99$ & 368.34 & 340.38 & $1.60 \%$ & $1.48 \%$ & 2.04 \\
\hline $\mathrm{D}$ & $414,383.98$ & $34,532.00$ & & $85 \mathrm{~m} 2$ & $10000 \mathrm{Kw}$ & $103,595.99$ & 605.13 & 559.09 & $1.75 \%$ & $1.62 \%$ & 3.06 \\
\hline $\mathrm{E}$ & $552,511.95$ & $46,042.66$ & & $110 \mathrm{~m} 2$ & $13000 \mathrm{Kw}$ & $129,083.89$ & $1,151.06$ & 892.89 & $2.50 \%$ & $1.94 \%$ & 4.07 \\
\hline $\mathrm{F}$ & $690,639.95$ & $57,553.33$ & & $150 \mathrm{~m} 2$ & $16500 \mathrm{Kw}$ & $129,494.98$ & $1,583.54$ & $1,165.86$ & $2.75 \%$ & $2.03 \%$ & 5.09 \\
\hline G & $828,767.94$ & $69,064.00$ & & $200 \mathrm{~m} 2$ & $20000 \mathrm{Kw}$ & $155,393.99$ & $2,014.37$ & $1,453.62$ & $2.92 \%$ & $2.10 \%$ & 6.11 \\
\hline $\mathrm{H}$ & $1,151,066.58$ & $95,922.22$ & & $200 \mathrm{~m} 2$ & $20000 \mathrm{Kw}$ & $207,191.98$ & $4,604.26$ & $3,568.31$ & $4.80 \%$ & $3.72 \%$ & 8.49 \\
\hline $\mathrm{I}$ & $1,352,503.24$ & $112,708.60$ & \multirow{3}{*}{$\begin{array}{l}\text { Venta de } \\
\text { Bs. } \\
\text { muebles }\end{array}$} & $200 \mathrm{~m} 2$ & $20000 \mathrm{Kw}$ & $207,191.98$ & - & $5,755.33$ & - & $5.11 \%$ & 9.97 \\
\hline $\mathrm{J}$ & $1,553,939.89$ & $129,494.99$ & & $200 \mathrm{~m} 2$ & $20000 \mathrm{Kw}$ & $207,191.98$ & - & $6,763.34$ & - & $5.22 \%$ & 11.46 \\
\hline $\mathrm{K}$ & $1,726,599.88$ & $143,883.32$ & & $200 \mathrm{~m} 2$ & $20000 \mathrm{Kw}$ & $207,191.98$ & - & $7,769.70$ & - & $5.40 \%$ & 12.73 \\
\hline
\end{tabular}

Fuente: Elaboración Propia. 
Tabla 3.2 Ingreso bruto promedio mensual por categoría del Régimen Simplificado para Pequeños Contribuyentes - Monotributo Argentino expresado en cantidad de sueldos mínimos peruanos (S/ 930)

\begin{tabular}{|c|c|c|c|c|c|c|c|c|c|c|c|}
\hline \multirow[b]{2}{*}{ Categ. } & \multicolumn{2}{|c|}{ Ingresos Brutos } & \multirow[b]{2}{*}{ Actividad } & \multirow[b]{2}{*}{$\begin{array}{c}\text { Sup. } \\
\text { Afectada }\end{array}$} & \multirow[b]{2}{*}{$\begin{array}{c}\text { Energía } \\
\text { Eléctrica } \\
\text { Consumida } \\
\text { Anualmente }\end{array}$} & \multirow[b]{2}{*}{$\begin{array}{c}\text { Alquileres } \\
\text { Devengados } \\
\text { Anualmente }\end{array}$} & \multicolumn{2}{|c|}{ Impuesto Integrado } & \multicolumn{2}{|c|}{$\%$ de ingreso bruto mensual } & \multirow{2}{*}{$\begin{array}{c}\text { Ingreso } \\
\text { bruto } \\
\text { promedio } \\
\text { mensual } \\
\text { expresado } \\
\text { en } \\
\text { Cantidad } \\
\text { de Sueldos } \\
\text { Mínimos } \\
\end{array}$} \\
\hline & $\begin{array}{c}12 \text { meses } \\
\text { acumulados }\end{array}$ & $\begin{array}{c}\text { Promedio } \\
\text { mensual }\end{array}$ & & & & & $\begin{array}{c}\text { Locaciones } \\
\text { y/o } \\
\text { Prestaciones } \\
\text { de Servicios }\end{array}$ & $\begin{array}{l}\text { Venta de } \\
\text { Cosas } \\
\text { Muebles }\end{array}$ & $\begin{array}{c}\text { Locaciones } \\
\text { y/o } \\
\text { Prestaciones } \\
\text { de Servicios }\end{array}$ & $\begin{array}{l}\text { Venta de } \\
\text { Cosas } \\
\text { Muebles }\end{array}$ & \\
\hline A & $11,368.06$ & 947.34 & \multirow{8}{*}{ No excluida } & $30 \mathrm{~m} 2$ & $3330 \mathrm{Kw}$ & $4,263.02$ & 9.20 & 9.20 & $0.97 \%$ & $0.97 \%$ & 1.02 \\
\hline $\mathrm{B}$ & $17,052.08$ & $1,421.01$ & & $45 \mathrm{~m} 2$ & $5000 \mathrm{Kw}$ & $4,263.02$ & 17.73 & 17.73 & $1.25 \%$ & $1.25 \%$ & 1.53 \\
\hline $\mathrm{C}$ & $22,736.11$ & $1,894.68$ & & $60 \mathrm{~m} 2$ & $6700 \mathrm{Kw}$ & $8,526.04$ & 30.31 & 28.01 & $1.60 \%$ & $1.48 \%$ & 2.04 \\
\hline $\mathrm{D}$ & $34,104.17$ & $2,842.01$ & & $85 \mathrm{~m} 2$ & $10000 \mathrm{Kw}$ & $8,526.04$ & 49.80 & 46.01 & $1.75 \%$ & $1.62 \%$ & 3.06 \\
\hline $\mathrm{E}$ & $45,472.22$ & $3,789.35$ & & $110 \mathrm{~m} 2$ & $13000 \mathrm{Kw}$ & $10,623.72$ & 94.73 & 73.49 & $2.50 \%$ & $1.94 \%$ & 4.07 \\
\hline $\mathrm{F}$ & $56,840.28$ & $4,736.69$ & & $150 \mathrm{~m} 2$ & $16500 \mathrm{Kw}$ & $10,657.55$ & 130.33 & 95.95 & $2.75 \%$ & $2.03 \%$ & 5.09 \\
\hline G & $68,208.33$ & $5,684.03$ & & $200 \mathrm{~m} 2$ & $20000 \mathrm{Kw}$ & $12,789.06$ & 165.78 & 119.63 & $2.92 \%$ & $2.10 \%$ & 6.11 \\
\hline $\mathrm{H}$ & $94,733.80$ & $7,894.48$ & & $200 \mathrm{~m} 2$ & $20000 \mathrm{Kw}$ & $17,052.08$ & 378.93 & 293.68 & $4.80 \%$ & $3.72 \%$ & 8.49 \\
\hline $\mathrm{I}$ & $111,312.21$ & $9,276.02$ & \multirow{3}{*}{$\begin{array}{c}\text { Venta de } \\
\text { Bs. muebles }\end{array}$} & $200 \mathrm{~m} 2$ & $20000 \mathrm{Kw}$ & $17,052.08$ & - & 473.67 & - & $5.11 \%$ & 9.97 \\
\hline $\mathrm{J}$ & $127,890.63$ & $10,657.55$ & & $200 \mathrm{~m} 2$ & $20000 \mathrm{Kw}$ & $17,052.08$ & - & 556.63 & - & $5.22 \%$ & 11.46 \\
\hline $\mathrm{K}$ & $142,100.70$ & $11,841.72$ & & $200 \mathrm{~m} 2$ & $20000 \mathrm{Kw}$ & $17,052.08$ & - & 639.45 & - & $5.40 \%$ & 12.73 \\
\hline
\end{tabular}

Fuente: Elaboración Propia. 


\subsection{El Régimen de Estimación Objetiva sobre el Impuesto a la Renta de las Personas Físicas (IRPF) Español}

Para la reforma tributaria del 2016, que se analizó en el capítulo II de este trabajo, el legislador en su exposición de motivos cita como legislación comparada a la española. Nosotros vamos a tomar la misma legislación para tratar de sustentar porque es válido mantener un régimen de Estimación Objetiva en el Perú, como lo es el Nuevo RUS.

Según Portillo N. (2003) cuando en el 1957 se lleva a cabo la gran reforma tributaria, en la que España incorpora en su legislación el Régimen de Estimación Objetiva "Global”, que consistía en:

[Englobar los] "beneficios de todos los que se dedican a una determinada industria en una provincia, ingresos de todos los que están adscritos a un Colegio profesional, etc. También pueden determinarse en función de estudios económicos, como muestreos estadísticos o estudios sobre consumo, todos ellos datos objetivos que no están basados en las declaraciones de cada sujeto pasivo. Una vez determinada la base, se aplican ciertos índices, signos o módulos, tales como número de trabajadores empleados, maquinaria o potencia instalada, que sirven para distribuir la cifra global entre todos los contribuyentes del grupo. (pág. 239)

Sostiene que la clave del éxito recaudatorio de este régimen, resultado de esta reforma, se da principalmente por que el contribuyente se ve libre de varias obligaciones adicionales que acompañan la Estimación Directa (régimen general del impuesto a la renta español). Añade que:

Para la utilización del método de estimación directa es necesario disponer de una capacidad de gestión e inspección por parte de la Administración Tributaria superior a la que se deriva de la utilización de estimaciones objetivas. Y ello fue fundamental en esta época, en la que la precariedad de medios por parte de la Administración Tributaria hacía muy complicado el seguimiento del fraude fiscal. Sin embargo, al establecer la estimación 
objetiva global, bien fuese a través de cuotas globales o bien de bases imponibles, aumentó la recaudación considerablemente. (pág. 240)

Entre las décadas de los 60 y 70, España empieza a detectar que empresas, que por su volumen de operaciones deberían tributar por el régimen de estimación directa, se estaban beneficiando del régimen de estimación objetiva, por lo que se empiezan a realizar modificaciones (exclusión de ciento tipo de contribuyentes, actividades, entre otros), llegando al régimen actual que es conocido como el Método de Estimación Objetiva "Singular”.

La Ley General Tributaria (2003):

“Art 52.-Método de estimación objetiva

El método de estimación objetiva podrá utilizarse para la determinación de la base imponible mediante la aplicación de las magnitudes, índices, módulos o datos previstos en la normativa propia de cada tributo" (Ley $58 / 2003)$.

El método de estimación objetiva español, a diferencia del monotributo argentino, no unifica en único pago el Impuesto a la Renta con el Impuesto al Valor agregado (IVA), por el contrario crea un Régimen especial simplificado del IVA exclusivo para los contribuyentes que tributan el Impuesto a la Renta con el Método de Estimación Objetivo.

La Agencia Estatal de Administración Tributaria (AEAT) en su página web añade: Una actividad sólo puede tributar en el régimen simplificado del IVA si tributa en estimación objetiva del IRPF. La coordinación entre ambos regímenes es total. La renuncia o exclusión en uno produce los mismos efectos en el otro.

Se aplica el régimen de estimación objetiva exclusivamente a empresarios y profesionales (solo incluidas determinadas actividades profesionales accesorias a otras empresariales de carácter principal), que cumplan los siguientes requisitos:

a. Que cada una de sus actividades esté incluida en la Orden del Ministerio de Hacienda y Administraciones Públicas que desarrolla el régimen de 
estimación objetiva y no rebasen los límites establecidos en la misma para cada actividad.

b. Que el volumen de rendimientos íntegros en el año inmediato anterior, no supere cualquiera de los siguientes importes:

- 250.000 euros para el conjunto de actividades agrícolas y ganaderas y forestales (modelo de la agricultura).

- $\quad 150.000$ euros para el conjunto de actividades económicas, excepto las agrícolas, ganaderas y forestales. Se computarán la totalidad de las operaciones, exista o no obligación de expedir factura. Las operaciones en las que exista obligación de expedir factura cuando el destinatario sea empresario, no podrán superar 75.000 euros (modelo del resto de los sectores productivos).

El rendimiento neto se calculará de acuerdo con lo dispuesto en la Orden [negrita añadida] que desarrolla este régimen, multiplicando los importes fijados para los módulos, por el número de unidades del mismo empleadas, utilizadas o instaladas en la actividad, o bien multiplicando el volumen total de ingresos, incluidas las subvenciones corrientes o de capital y las indemnizaciones, por el índice de rendimiento neto que corresponda cuando se trate de actividades agrícolas, ganaderas y forestales.

La Orden ministerial [negrita añadida] en cuya virtud se fijen los signos, índices o módulos aplicables a cada actividad contendrá las instrucciones necesarias para su adecuado cómputo y deberá publicarse en el «Boletín Oficial del Estado» antes del 1 de diciembre anterior al período a que resulte aplicable. Podrá referirse a un período de tiempo superior al año, en cuyo caso se determinará por separado el método de cálculo del rendimiento correspondiente a cada uno de los años comprendidos (Real Decreto 439/2007).

Con la Orden HAC/1264/20187 se desarrollan para el año 2019 el método de estimación objetiva del Impuesto sobre la Renta de las Personas Físicas y el régimen especial simplificado del Impuesto sobre el Valor Añadido. Documento 
de ochenta y seis (86) paginas, que incluye dos (2) con las actividades a incluir en el mencionado método (una con actividades afectas al IVA y otra con las inafectas), la tabla de magnitudes que generan la exclusión del régimen por actividad (trabajadores, .empleados o vehículos). Se incluyen dos (2) anexos con las tablas que establecen los parámetros, índices que difieren según la actividad afecta a este régimen. Asimismo, contempla la posibilidad de aplicar índices correctores para circunstancias especificadas (dimensión, temporada, exceso sobre cuántica establecida por actividad, nuevas actividades).

La obligación de declarar es anual, pero se trimestralmente se deberá realizar un pago a cuenta o fraccionado.

Este régimen se encuentra parametrizado por el tipo de actividad.

\subsection{Simplificación Tributaria Italiana}

Similar a la legislación peruana, en el ordenamiento jurídico italiano no existe una sola noción de pequeña empresa. Al respecto Perone (2006) señala que:

Se trata de un término polisémico cuyo significado depende de la disciplina jurídica que regule la materia. Así, mientras en el Derecho tributario se atiende a criterios económicos y patrimoniales asumiéndose como parámetros el volumen de renta, consistencia patrimonial, etc; en el derecho laboral se define la pequeña empresa atendiendo al número de trabajadores o bien en derecho comercial, donde el pequeño empresario es aquél que organiza y dirige la propia actividad prevalentemente con el trabajo propio y el trabajo de los propios familiares contratados (citado por Andrés A., 2006).

El ordenamiento tributario italiano contempla distintas modalidades estimación objetiva de bases imponibles y otras técnicas de simplificación en el Impuesto a la Renta y en el Impuesto sobre el valor añadido, con la idea de simplificar al máximo las obligaciones:

\section{Régimen "forfettario";}

Régimen para las actividades marginales ("per le attività marginali”) 
- Régimen para las nuevas iniciativas empresariales y trabajadores autónomos.

\subsubsection{Régimen "forfettario" o de tarifa plana}

Creado con la Ley No 662/1996 del 23 de diciembre de 1996 (Ley de acompañamiento a la Ley de Presupuestos para 1997), en relación a los períodos impositivos iniciados a partir del 1 de enero de 1997, otorga la posibilidad de hallar de forma forfetaria el IVA y el Impuesto sobre la Renta de la empresa o del trabajo autónomo.

Andres A. (2006) enumera que se caracteriza por:

Aplicarse a empresarios individuales personas físicas, profesionales y artistas que en el año precedente:

- No hayan realizado un volumen de negocios superior a 10.329,14 euros.

- No hayan utilizado bienes amortizables cuyo valor neto contable sea superior a 10.329,14 euros.

No hayan realizado exportaciones.

No hayan efectuado pagos por asalariados y colaboradores superiores al $70 \%$ del volumen de negocio.

Este régimen dejará de aplicarse en el año sucesivo a aquél en el cual deje de cumplirse alguna de las condiciones expuestas.

Para los contribuyentes que siguen el régimen forfetario están previstas importantes simplificaciones contables. Entre ellas:

- $\quad$ La posibilidad de no emitir factura salvo que así lo pida el cliente.

- La obligación de pedir y conservar la documentación de las compras de la actividad, sin que deba ser registrada en el Libro IVA de compras.

- Deben anotar las operaciones efectuadas en el registro de las facturas dentro de los 15 días del mes siguiente, o en su caso, 
en el apposito prospetto que sustituye al registro anterior, cuyo contenido se prevé en el D.M. 12/2/1997.

En el caso de las empresas personas físicas o profesionales acogidos al régimen forfetario, la determinación de la renta sujeta a gravamen se obtiene -como determina la propia denominación del régimen- de forma forfetaria, esto es aplicando un porcentaje al conjunto del "Volumen de negocios" (aumentado en los ingresos por ventas y prestaciones de servicios no relevantes a los efectos de la aplicación del IVA.)

Las alícuotas aplicables son las siguientes:

- $\quad$ Empresas que tienen por objeto prestaciones de servicios: $75 \%$

- $\quad$ Empresas que tiene por objeto otra actividad: $61 \%$

- $\quad$ Empresas que ejercen arte o profesión: 78\%

Asimismo, el IVA se calcula de forma forfetaria con relación a la actividad prevalentemente ejercitada, sobre la base de la porcentual que a continuación se indica, porcentaje que se aplica sobre el tipo impositivo del IVA correspondiente a la operación de que se trate sujeta a gravamen ${ }^{8}$

- $\quad$ Empresas que tienen por objeto prestaciones de servicios: $73 \%$

- $\quad$ Empresas que tiene por objeto otra actividad: $60 \%$

- $\quad$ Empresas que ejercen arte o profesión: 84\%

La simplicidad de este régimen consiste en la simplificación de obligaciones contables, reducido al mínimo indispensable, y al cálculo del rendimiento, la renta sujeta a gravamen se determina aplicando un porcentaje (plano) al volumen del negocio. 


\subsubsection{Régimen para las actividades marginales ("per le attività marginali" $o$}

\section{"forfettone")}

El artículo $14^{\circ}$ de la Ley $N^{o} 388 / 2000$, crea este régimen fiscal preferente aplicable a los sujetos que realizan actividades empresariales o trabajadores autónomos incluidos en los estudios de sectores aprobados por el Ministerio de Finanzas italiano (similar al método de Estimación Objetiva Español). A ellos les son aplicables simplificaciones documentales y contables, amén de poder determinar la renta sujeta a gravamen de forma forfetaria.

Andres A. (2006) enumera que se caracteriza por:

Aplicarse a personas físicas que ejercen actividades empresariales, profesionales y artísticas, así como a empresas familiares que se hallen acogidas a los estudios de sectores y que cumplan una serie de condicionantes que a continuación se indican:

- Que la actividad realizada esté incluida entre aquéllas efectivamente sujetas al estudio de sectores.

Que los ingresos por cesión de bienes y prestación de servicios del período impositivo anterior no sean superiores al límite individualizado al efecto por Decreto Ministerial en función de las dimensiones medias de los operadores del sector. Tal límite, que variará en función del sector de actividad, no puede en ningún caso ser superior a 25.822,85 euros.

Este régimen fiscal preferente para actividades marginales consiste en la aplicación de un impuesto reducido que se calcula a "forfeit" (15\%). Esto es: se aplica un impuesto sustitutivo del 15\% sobre la renta sujeta a gravamen.

La renta sujeta a gravamen se obtiene por diferencia entre los ingresos provenientes de la venta de bienes o de la prestación de servicios (calculados según las reglas del estudio de sectores) y los costes y gastos determinados según las reglas previstas para la actividad de la empresa en régimen de contabilidad simplificada. 
El tiempo de aplicación de este régimen es indefinido, salvo que se den las causas por las que debe dejar de observarse o bien se renuncie al mismo. La opción es válida al menos por un año impositivo, renovable automáticamente cuando vence o bien por renuncia o por causa sobrevenida de cesación del mismo.

De manera similar a lo que ocurre en el caso del régimen forfetario, una de las principales ventajas de este sistema es que los sujetos a él acogidos están exonerados de llevar los libros contables del IRPF, IVA, e impuesto de actividades económicas de carácter local, así como de la liquidación y pagos "periódicos" en materia de IVA (solo declaración y pago "anual”).

No obstante lo anterior, tienen las siguientes:

- Conservar los documentos contables: recibidos y emitidos.

- $\quad$ Emitir factura o recibo fiscal, en su caso.

- $\quad$ Presentar las declaraciones anuales.

\subsubsection{Régimen para las nuevas iniciativas empresariales y trabajadores} autónomos

El artículo $13^{\circ}$ de la Ley $\mathrm{N}^{\circ} 388 / 2000$, crea este régimen que permite incentivar a las personas que realicen nuevas iniciativas empresariales.

Andres A. (2006) enumera que se caracteriza por:

Aplicarse a personas físicas que realicen actividades artísticas, profesionales o de empresa durante los períodos impositivos en los que empiecen la actividad y los dos sucesivos. Esto es, pueden aplicar el régimen en los tres primeros años de actividad.

La principal ventaja de este régimen es que se realiza un pago sustitutivo del Impuesto sobre la Renta de las Personas Físicas que consiste en aplicar una alícuota del $10 \%$.

Es importante reseñar el hecho de que de darse tales condiciones dicho régimen se aplicará por defecto, salvo que se elija el régimen 
ordinario o simplificado o bien se superen los límites para poder acogerse al mismo.

Para poder acogerse al régimen de empresa de nueva iniciativa deben darse las siguientes circunstancias:

Que se trate de personas físicas o de empresa familiar o bien profesionales o artistas.

Que los contribuyentes admitidos no hayan ejercitado en los tres últimos años actividad artística, profesional o de empresa, pues lo que se pretende es incentivar las nuevas iniciativas productivas.

- Que la nueva actividad emprendida no constituya la continuación de otra que se ejercía anteriormente desarrollada bajo la cualidad de trabajador dependiente o autónomo. Se excluyen los períodos de práctica en el ejercicio de arte o profesión.

Que las cantidades de ingresos del trabajo autónomo o de ingresos por actividad empresarial no superen los siguientes límites. A saber.

- Las sumas por actividad de trabajo autónomo no deben superar la cantidad de 30.987,41 euros (ingresos $\leq \mathrm{a}$ $30.987,41$ euros).

- Los ingresos por prestación de servicios deben ser $\leq \mathrm{a}$ $30.987,41$ euros

- Para actividades distintas a aquéllas: ingresos $\leq$ $61.974,83$ euros.

- En el caso de que se realicen simultáneamente ambos tipos de actividades se estará a la actividad prevalente, esto es, a la que produzca un mayor volumen de ingresos.

- Los sujetos acogidos a este régimen deberán cumplir las obligaciones sociales y administrativas.

Es importante destacar que esta tasación forfetaria de la renta de los empresarios o trabajadores autónomos a través de la aplicación de un impuesto sustitutivo (10\%) únicamente sustituye al IRPF. 
Dicha alícuota se aplica directamente sobre la renta obtenida sin poderse aplicar deducciones en dicha renta (por ejemplo el contribuyente no deduce ni la seguridad social, ni tampoco otro tipo de gastos). Tales contribuyentes siguen estando sujetos al IVA según criterios ordinarios.

Transcurrido el tercer año, no se podrá seguir gozando del régimen preferencial de nueva actividad, debiendo acogerse a otro régimen. En relación a las obligaciones formales, son las mismas que tiene el régimen para las actividades marginales.

\subsubsection{Estudios de Sector}

Los estudios de sector se crean con el D.L. No 331 del 30 de agosto de 1993, convertido en Ley No 427 el 29 de octubre de 1993. Sin embargo, solo desde 1998 los estudios sectoriales han reemplazado progresivamente los supuestos parámetros de ingresos, compensación y facturación, que constituían el instrumento de control utilizado anteriormente (Cámara de Comercio de Turín).

Andres A. (2006) lo define como:

Con carácter general, puede afirmarse que los estudios de sector son un instrumento utilizado para valorar la capacidad de producir ingresos derivados de la venta de bienes o prestación de servicios derivados de la realización de las actividades económicas individualizadas (Gli studi di settore, en www.agenziaentrate.it). Constituyen un instrumento utilizable por la administración para la reconstrucción inductiva de los ingresos producidos.

Individualizan los elementos que caracterizan la actividad de cada sector con particular referencia a las adquisiciones de bienes o servicios, a los precios practicados, a los consumos de materias primas y subsidiarias, al capital invertido, al desarrollo de la actividad laboral, a los bienes instrumentales empleados, a la localización de la actividad y otros elementos significativos. Su 
elaboración se basa en un sistema experto, construido sobre métodos matemático-estadístico que debería constituir un instrumento esencial para la recuperación de la eficiencia de la máquina fiscal en especial en su lucha contra la evasión fiscal. (pág. 18)

Los estudios sectoriales se dividían en cuatro grupos: servicios, comercio, fabricación y Actividades profesionales.

Dentro de cada grupo, los estudios sectoriales se dividían en categorías homogéneas de actividades (denominados "clusters"), organizadas según los mismos criterios taxonómicos que la tabla de actividades económicas de Ateco. Se caracterizaban por una letra que indica el grado de "evolución" (es decir, revisión o actualización): La letra "T" indicaba los estudios revisados y la letra "U" para los revisados por segunda vez.

Vale precisar que a partir del 2019 estos fueron reemplazados por los, o cambiaron de nombre a, Índices Resumidos de Confiabilidad Fiscal - Indici Sintetici di Affidabilità fiscale (ISA) que se aplicarán a las declaraciones de impuestos relacionadas con el año fiscal 2018, aprobados con la Orden del director de la Agencia el 30 de enero de 2019 y se modificaron posteriormente con la Orden del Director de la Agencia de 15 de febrero de 2019 y 10 de mayo de 2019.

Los regímenes simplificados del ordenamiento italiano vienen acompañados del servicio de asistencia gratuita a cargo de la Administración de la Agencia Tributaria Italiana.

\subsection{Conclusiones preliminares}

El problema de la informalidad (evasión) es común en los países de América Latina, donde juega un papel importante la percepción que tiene la ciudadanía del 
Estado y la Administración Tributaria, y en el que algunos generadores de rentas son informales porque el costo de la formalización es alto.

Asimismo, del análisis de la legislación comparada realizada en este capítulo, podemos concluir que la tendencia en relación a los regímenes simplificados no es eliminarlos, sino perfeccionarlos, tener niveles de categorías con parámetros progresivos a fin de acercarse en lo más posible a la capacidad contributiva de los contribuyentes. Algo a lo que apuntaba también el sistema tributario peruano cuando creo el Nuevo RUS (Punto 1.3.1. Decreto Legislativo $\mathrm{N}^{\circ}$ 937, categorización cuatrimestral con parámetros).

Los regímenes analizados, y el Nuevo RUS, tienen en común: estar dirigidos a personas naturales (personas físicas) y ser voluntario (el potencial contribuyente puede elegir entre acogerse a un régimen simplificado o uno general). 


\section{CAPÍTULO IV: ASPECTOS A CONSIDERAR EN EL PERFECCIONAMIENTO DEL NUEVO REGIMEN ÚNICO SIMPLIFICADO EN EL PERÚ}

\subsection{La Administración Tributaria - SUNAT}

La SUNAT es la entidad responsable solo de aplicar la norma tributaria. El énfasis en el "solo" se debe a que muchas veces los contribuyentes o los ciudadanos en general tienen la percepción de que son:

Responsables de la emisión de las normas tributarias, cuando su papel se limita a ser el ente técnico al que le deberían recurrir los legisladores. Vale precisar que muchas de las obligaciones formales de los contribuyentes si se encuentran normados por Resoluciones de Superintendencia emitidas por está (Por ejemplo, formulario y formas de presentarlos).

- Responsables de la ejecución del Gasto Público, generado por el hecho de que quien nos cobra y a quien le pagamos es SUNAT, se asume que quien ejecuta presupuesto, que quien "gasta mal nuestro dinero" es esta institución.

La dañada imagen de la SUNAT es aprovechada coyunturalmente por políticos o personajes públicos, quienes en lugar de educar a la población sobre la importante labor que está ejecuta, la desautoriza. Es fácil odiar al ente que te cobra impuesto, nadie quiere pagar impuestos, pero dejamos de lado que la recaudación tiene como fin cubrir el Gasto Publico.

No podemos negar, que existen procesos a cargo de la SUNAT que vienen atrasado en relación con otros países: las declaraciones tributarias automatizadas, los comprobantes electrónicos y los libros electrónicos. Proceso que han jugado un papel clave en el proceso de simplificación de esos países. 
Una de las principales deficiencias de la SUNAT, además de una página web institucional poco amigable, son los constantes inconvenientes de plataforma informática, que los lleva a otorgar prorrogar ${ }^{9}$ o medidas discrecionales para la no emisión de multas por infracciones en las que incurren los contribuyentes. Esta situación genera una sensación de inseguridad y falta de predictibilidad para los contribuyentes $¿$ Trato de cumplir en plazo o espero la prórroga?

La SUNAT debe abocarse a brindar un servicio de calidad a los contribuyentes, en estabilizar sus plataformas informáticas, el incremento de obligaciones formales no solo afecta al contribuyente que las tiene que cumplir, sino también a la Administración que tiene que controlarlas. Tal como lo han hecho otros países, este debe ser un proceso progresivo.

El Estado debe tomar medidas para incentivar la Conciencia o Cultura Tributaria, la importancia de tributar.

\subsection{Análisis del costo-beneficio de perfeccionar el Nuevo RUS}

La lucha contra la informalidad debe cumplir las siguientes características:

- $\quad$ Debe ser poco (o nulo) el costo de formalización.

- $\quad$ Debe ser beneficioso.

- $\quad$ Debe ser sencillo.

Un régimen en base a estimaciones como el RUS es válido en países como el nuestro, reduce el número de contribuyentes a fiscalizar, considerando que la SUNAT no tiene la capacidad operativa de fiscalizar al total directorio de contribuyentes, y debe priorizar por importancia fiscal (volumen de ingresos). E incluso, su simplicidad abarata los costos del control y fiscalización que se deben asumir.

http://www.sunat.gob.pe/mensajes/mensajes-SUNAT.html 
Por ejemplo, los regímenes simplificados analizados en el capítulo anterior requieren que los contribuyentes presenten una declaración jurada de los parámetros en los que se encuentran a fin de sustentar la categoría en la que van a pagar. Este solo es reemplazado si existe variación en alguno de los parámetros. Aunque el contribuyente asume dicha carga, esta le otorga un régimen que una garantiza "Estabilidad Tributaria" temporal. El contribuyente tiene claro cuánto va a pagar durante ese periodo, y la Administración cuándo debe cobrar, incluso cuando no hay ingresos que declarar. Lo que se tiene que fiscalizar es si el contribuyen de categorizo correctamente, al igual que en el Nuevo RUS. Siendo la principal diferencia que en el caso del Nuevo RUS la categorización es mensual, la Administración que fiscaliza doce (12) meses, tiene que revisar la misma cantidad de categorizaciones, mientras que en el Argentino, por ejemplo, la categorización es semestral, por lo que son solo dos (2) las categorizaciones a revisar.

\subsection{Propuesta de mejoras}

Se debe retomar el proceso de perfeccionamiento de Régimen Único Simplificado que se inició con el Decreto Legislativo $N^{\circ} 937$.

Aunque no se debieron eliminar las categorías 3 a la 5 del Nuevo RUS, no bastaría con reactivar estas categorías.

En nuestra opinión, el Nuevo RUS requiere incluir las siguientes características normativas:

- Incluir parámetros que permitan limitar a los contribuyentes que pueda acceder a este régimen tributario (actividades) y reducir la brecha entre la carga tributaria y la capacidad contributiva que se pueda generar resultado del régimen. 
- Actualización anual de los paramentos en base a Indicadores Económicos imparciales como la Unidad Impositiva Tributaria, la Remuneración Mínima Vital o la inflación

Somos de la opinión de que el tener un régimen simplificado similar al argentino: categorías debajo de la actual en el Nuevo RUS (ingresos menores a S/ 5,000 mensual), y gravámenes menores al actual (S/ 20) se podría incentivar con mejores resultados la incorporación de informales a la base tributaria. Asimismo, el contar con categorías con ingresos altos, como los S/ 30,000 de la categoría 5, derogado en la última reforma tributaria, le da la posibilidad de decidir al contribuyente si se queda en el Nuevo RUS, con un monto alto de pago definitivo (que podría ser mayor al derogado), o migrar a un régimen tributarios de mayores costos de cumplimiento, pero donde puede que termine pagando menos (economía de opción). El tener un sistema tributario donde te ves obligado a migrar de un periodo a otro porque generaste ingresos mayores, muchas veces lleva a los contribuyentes a recurrir a la informalidad o modalidades de evasión (Por ejemplo, declarar ingresos menores a los generados para no ser excluidos del régimen, debiendo dejar de emitir comprobantes por todas las ventas y/o escondiendo los comprobantes de las adquisiciones realizadas).

La SUNAT, debe retomar sus acciones de:

Fiscalización de obligaciones formales dirigida a personas naturales que comercializan con consumidores finales; tales son la verificación de emisión de comprobantes de pago, aunque esto lleve a que sancione a los contribuyentes con el tan criticado "Cierre Temporal". La discrecionalidad no debe ser generalizada a todos los contribuyentes, lo establecido en la Resolución de Superintendencia $\mathrm{N}^{\circ}$ 200-2016-SUNAT genero la percepción equivocada, de que cuando SUNAT sanciono, fue injusta.

- Incentivo a los contribuyentes para el cumplimiento de la obligación de exigir comprobantes de pago con la modalidad del "Sorteo de Comprobantes de Pago", dirigido a ciudadanos y escolares. 
Aunque los contribuyentes del Nuevo RUS pueden emitir comprobantes electrónicos (desde la entrada en vigencia de la Resolución de Superintendencia $\mathrm{N}^{\circ}$ 340-2017/ SUNAT y normas modificatorias), este no es la modalidad más común de este régimen. Por lo que sugerimos modificar el Decreto Supremo $N^{\circ}$ 248-2018-EF e incluir a todos los comprobantes de pago que se pueden emitir en este régimen como sustento válido para la deducción de gasto adicional.

Se tiene que entender que cualquier medida que logre una ampliación en la base tributaria va a generar un incremento en la recaudación. Asimismo, si las obligaciones tributarias son simples, el nivel de cumplimiento de estas también mejora. 


\section{CONCLUSIONES}

Las reformas tributarias más importantes de nuestro Sistema Tributario han salido del Poder Ejecutivo, resultado de la delegación de facultades para legislar (Poder Legislativo), pero la eficiencia depende de la buena relación de ambos poderes.

1. Las reformas tributarias deben buscar simplificar el sistema, reducir la informalidad con la ampliación de la base tributaria y la reducción de los altos costos de cumplimiento tributario. Cuando estas se dan por delegación de facultades, se encuentran condicionadas a la relación política que tengan ambos poderes (Poder Ejecutivo y Poder Legislativo).

2. Una reducción de las tasas impositivas no tiene impacto en la informalidad. Una empresa informal (por ejemplo, persona natural con negocio no registrado en SUNAT, sin RUC, y que por ende no tributa) si le reduces la tasa del impuesto a pagar, considerando que el pago actual es cero (una reducción de cero siempre será cero), no va a tener incentivo de formalizarse. Como han concluido varios de los autores citados, los empresarios informales no se van a ver atraídos por un régimen tributario de menor tasa, sino por un régimen que le otorgue beneficios. Incluso, uno de estos beneficios puede ser la tranquilidad de estar en la formalidad, pero sin tener que asumir una gran carga tributaria.

3. La carga tributaria de un régimen tributaria no solo afecta al contribuyente, sino también a la Administración Tributaria. La carga tributaria del contribuyente no se limita al monto a pagar (tasa o cuota fija), sino a que tan complicado se le va a ser cumplir con las obligaciones tributarias que implica ser formal. El Régimen Tributario MYPE incentivo a los contribuyentes, cuya carga tributaria antes de este régimen era mayor, a mantenerse en la formalidad. Pero por otro lado los 
contribuyentes del Nuevo RUS, que de oficio migraron a este régimen, han visto incrementado esta carga, al asumir mayores obligaciones formales.

4. De la legislación comparada, se concluye que esta tendencia internacional usar los regímenes simplificados como herramienta para reducir la informalidad e incentivar el emprendimiento, con mejoras progresivas.

5. El Estado, que incluye a la SUNAT, debe ejecutar acciones a fin de incentivar la Cultura o Conciencia Tributaria.

6. Que sin importar hacia donde apunte finalmente la política tributaria, ya sea eliminar o perfeccionar el Nuevo RUS, la SUNAT requiere tomar medidas para superar los constantes inconvenientes presentados en su plataforma informática. 


\section{RECOMENDACIONES}

A continuación, listaremos las recomendaciones desarrolladas durante el trabajo de investigación:

1. Las reformas tributarias deben contar con la opinión técnica del ente especialista, a nuestra opinión la SUNAT. Estas deben ser comunicadas a la población en términos sencillos y simples, al menos las que van a afectar sus posibilidades de desarrollo y bienestar, para que, si no se logra el respaldo político en el Congreso, se tenga el apoyo de la población. No basta con Transparencia, se requiere simplicidad en la comunicación entre el Estado y la ciudadanía.

2. Las medidas dirigidas a reducir la informalidad deben apuntar a incentivar al contribuyente otorgando facilidades o beneficios. Por ejemplo, "Inducción a la Informalidad" periodos de "gracia" con la exoneración de la obligación del pago de impuestos, pero manteniendo la obligación de declarar a fin de que el contribuyente se familiarice con el proceso. Contando con el acompañamiento de la Administración Tributaria en ese proceso. Tenemos el caso Argentino, que reintegra el pago de la cuota de un mes por el pago con débito automático.

3. El emprendimiento empresarial tiene un efecto positivo en la economía del país, por lo tanto, el Estado debe garantizar que el emprendedor tenga como única preocupación el desarrollo de su negocio. El Sistema Tributario debe garantizar que las obligaciones tributarias sean simples de entender y cumplir. De ese modo, llegado el momento se pueden implementar medidas que permitan facilitar el control por parte de la Administración (mayor volumen de ingresos, mayor control), generando mayor carga para el administrado, la que debe ir acompañada de medidas de la Administración que faciliten ese proceso. Por ejemplo, se deben 
brindar canales de atención de consultas, las que deben ser vinculantes para la Administración Tributaria. Para que el contribuyente tenga la certeza de que no está incurriendo en errores.

4. Se debe perfeccionar el Nuevo RUS, incluyendo las buenas prácticas de otros países:

a. Incluir más categorías, las que deben estar definidas en parámetros basados en índices económicos (Argentina) o por actividades Específicas (Italia) o ambas (España).

b. Limitarlo a contribuyentes Personas Naturales Físicas, establecer límites máximos para la permanencia de las sucesiones indivisas en este régimen.

5. SUNAT debe retomar las acciones de fiscalización dirigidas a contribuyentes informales (personas naturales con negocio), no con el fin de generación de riesgo entre ellos. Asimismo, debe promover la emisión de comprobantes de pagos y la cultura tributaria con los ya conocidos "Sorteo de Comprobantes de Pago" o 'la inclusión de los comprobantes físicos para el sustento adicional de gasto deducible del Impuesto a la Renta de Personas Naturales.

6. La más importante: SUNAT debe avocar sus acciones a estabilizar sus plataformas informáticas. Por ejemplo, si tengo problemas en los módulos de emisión de comprobantes de pago, ¿para qué incorporar nuevos obligados? Las constantes prórrogas en la vigencia de obligaciones formales electrónicas, por los problemas en sus plataformas, dañan más la imagen ya dañada de la Administración Tributaria. 


\section{REFERENCIAS}

Acevedo Damián, K. (2007). En Lima, Mypes ven la formalidad como un perjuicio por alta rigidez. Recuperado el 24 de Septiembre de 2017, de sitio Web de Actualidad Empresarial: http://aempresarial.com/web/informativo.php?id=2795

Administración Federal de Ingresos Públicos. (s.f.). Definición de Monotributo. Obtenido de sitio Web le la https://monotributo.afip.gob.ar/Public/Ayuda/Index.aspx

Agencia Estatal de Administración Tributaria (AEAT). (s.f.). Estimación Objetiva. Obtenido de sitio Web de la AEAT: https://www.agenciatributaria.es/AEAT.internet/Inicio/_Segmentos_/Empresas_ y_profesionales/Empresarios_individuales_y_profesionales/Rendimientos_de_a ctividades_economicas_en_el_IRPF/Regimenes_para_determinar_el_rendimien to_de_las_actividades_economicas/Es

Aguirre Lanari, J. R. (3 de Junio de 1998). Senado de la Nación Argentina - Régimen tributario especial para pequeños contribuyentes. Versión taquigrafica de la $22^{\circ}$ Reunión - $14^{\circ}$ Sesión ordinaria. Obtenido de http://www.senado.gov.ar/parlamentario/sesiones/03-06-1998/22/downloadTac

Andrés Aucejo, E. (2006). A propósito de la simplificación impositiva en Derecho Comparado: la Contabilidad simplificada en Italia y los "Estudios de Sector" para el cálculo presuntivo de las liquidaciones tributarias. Obtenido de http://hdl.handle.net/2445/15504

Arias Minaya, L. A. (2018). El Perú hacia la OCDE - La agenda pendiente para la política tributaria 2018-2021 (Primera ed.). Lima: Grupo de Justicia Fiscal.

Cámara de Comercio de Turín. (s.f.). Gli studi di settore. Obtenido de sitio web de la Cámara de Comercio de Turín: https://www.to.camcom.it/book/export/html/6136

Constitución Política del Perú. (1993). Obtenido de http://www4.congreso.gob.pe/ntley/Imagenes/Constitu/Cons1993.pdf 
Decreto Legislativo No 1258. (8 de Diciembre de 2016). Decreto Legislativo que modifica la Ley del Impuesto a la Renta. Perú. Obtenido de https://busquedas.elperuano.pe/normaslegales/decreto-legislativo-que-modificala-ley-del-impuesto-a-la-re-decreto-legislativo-n-1258-1461978-3/

Decreto Legislativo No 1269. (20 de Diciembre de 2016). Decreto Legislativo que crea el Régimen MYPE Tributario del Impuesto a la Renta. Lima, Perú. Obtenido de http://busquedas.elperuano.com.pe/normaslegales/decreto-legislativo-que-creael-regimen-mype-tributario-del-decreto-legislativo-n-1269-1465277-1/

Díaz Saavedra, S. (2011). Principios Constitucionales Tributarios en el Derecho Comparado. Obtenido de sitio Web de la Revista Jurídica - Universidad Católica de Santiago de Guayaquil: https://www.revistajuridicaonline.com/wpcontent/uploads/2011/05/121_a_166_principios_const.pdf

Gleiser, S. (4 de Abril de 2014). El 65\% de todas las empresas en el Perú son informales. Obtenido de sitio Web del diario El Comercio: https://elcomercio.pe/economia/peru/65-empresas-peru-son-informales-168604

Ley 58/2003. (17 de Diciembre de 2003). Ley General Tributaria. España.

Ley $\mathrm{N}^{\circ}$ 27.430. (27 de Diciembre de 2017). Ley de Impuesto a las Ganancias. Argentina. Obtenido de http://servicios.infoleg.gob.ar/infolegInternet/verNorma.do?id=305262

Ley $\mathrm{N}^{\mathrm{o}}$ 24.977. (2 de Julio de 1998). Régimen Simplificado para Pequeños Contribuyentes. Argentina. Obtenido de http://servicios.infoleg.gob.ar/infolegInternet/anexos/5000054999/51609/texact.htm

Ley $\mathrm{N}^{\circ}$ 27.346. (27 de Diciembre de 2016). Ley de Impuesto a las Ganancias, IVA y Regimen Simplificado para Pequeños Contribuyentes. Argentina. Obtenido de http://servicios.infoleg.gob.ar/infolegInternet/verNorma.do?id=269773

Ley $\mathrm{N}^{\text {o } 30506 . ~(9 ~ d e ~ O c t u b r e ~ d e ~ 2016) . ~ L e y ~ q u e ~ d e l e g a ~ e n ~ e l ~ p o d e r ~ e j e c u t i v o ~ l a ~ f a c u l t a d ~}$ de legislar en materia de reactivación económica y formalización, seguridad ciudadana, lucha contra la corrupción, agua y saneamiento y reorganización de Petroperú S.A. Lima, Perú. Obtenido de 
http://busquedas.elperuano.com.pe/normaslegales/ley-que-delega-en-el-poderejecutivo-la-facultad-de-legislar-ley-n-30506-1439097-1/

Luna, J. (25 de Agosto de 2016). Cuatro de cada cinco PYMEs son informales: ¿Es suficiente reducir el IGV? Obtenido de sitio Web del Diario Gestión: https://gestion.pe/economia/cuatro-cinco-pymes-son-informales-suficientereducir-igv-147423

Ministerio de Economía y Finanzas - MEF. (s.f.). Lineamientos de Política Tributaria. Obtenido de sitio web del MEF: https://www.mef.gob.pe/es/lineamientos-depolitica-tributaria

Ministerio de Economía y Finanzas. (2016). Exposición de Motivos del Decreto Legislativo $N^{\circ}$ 1258. Obtenido de sitio Web del Congreso de la República: http://www.congreso.gob.pe/Docs/comisiones2016/ConstitucionReglamento/file s/1258_ultimo.pdf

Ministerio de Economía y Finanzas. (2016). Exposición de Motivos del Decreto Legislativo $N^{\circ}$ 1269. Obtenido de sitio Web del Congreso de la República: http://www.congreso.gob.pe/Docs/comisiones2016/ConstitucionReglamento/file s/exposici\%C3\%B3n_de_motivos_dl_1269.pdf

Ministerio de Economía y Finanzas. (2016). Exposición de Motivos del Decreto Legislativo $N^{\circ}$ 1270. Obtenido de sitio Web del Congreso de la República: http://www.congreso.gob.pe/Docs/comisiones2016/ConstitucionReglamento/file s/exposici\%C3\%B3n_de_motivos_dl_1270.pdf

Moreno, C. (Enero de 2002). La importancia de ser formal. Tributemos SUNAT(104). Recuperado el 24 de Septiembre de 2017, de Superintendencia Nacional de $\begin{array}{lllll}\text { Aduanas } & y & \text { de } & \text { Administración }\end{array}$ http://www.sunat.gob.pe/institucional/publicaciones/revista_tributemos/tribut10 4/index.htm

Navarrete Maldonado, A. J. (2014). Régimen Normativo MYPE y sus recientes modificaciones (1 ed.). Lima: Gaceta Juridica.

Partido Político Peruanos por el Kambio. (2016). Plan de Gobierno del Partido PPK 2016 - 2021. Recuperado el 24 de Setiembre de 2017, de sitio Web Partido 
$\begin{array}{lllll}\text { Político } & \text { Peruanos } & \text { por }\end{array}$

http://www.peruanosporelkambio.pe/documentos/plandegobierno.pdf

Peñaranda Castañeda, C. (2014). Ingresos del trabajador formal superan en $80 \%$ a los del Informal. (N. Zavaleta Montoya, Ed.) La Camára, 6-8. Obtenido de sitio Web de la Camara de Comercio de Lima: https://www.camaralima.org.pe/RepositorioAPS/0/0/par/EDICION632/Ediciond igital\%20632.pdf

Portillo Navarro, M. J. (2003). Evolución histórica del impuesto sobre rendimientos del trabajo personal y resultados recaudatorios. Anales de Derecho(21), 239-251. Obtenido de https://digitum.um.es/digitum/bitstream/10201/11357/1/AD21\%202003\%20p\% 20239251.pdf

Presidencia del Consejo de Ministros. (8 de Septiembre de 2016). Proyecto de Ley 228/2016-PE. Obtenido de sitio Web del Congreso de la República: http://www.leyes.congreso.gob.pe/Documentos/2016_2021/Proyectos_de_Ley_ y_de_Resoluciones_Legislativas/PL0022820160908..pdf

Real Academia Española (RAE). (2018). Informal. En Diccionario de la lengua española. Obtenido de sitio Web de la Real Academia Española: https://dle.rae.es/srv/search?m=30\&w=informal

Real Decreto 439/2007. (30 de Marzo de 2007). Reglamento del Impuesto sobre la Renta de las Personas Físicas y se modifica el Reglamento de Planes y Fondos de Pensiones. España.

Saavedra P., M. (2 de Diciembre de 2016). INEI: Los impresionantes números del sector informal peruano. Obtenido de sitio Web del Diario El Comercio: https://elcomercio.pe/economia/peru/inei-impresionantes-numeros-sectorinformal-peruano-229623

Shiguiyama Kobashigawa, V. (23 de Setiembre de 2017). Sunat plantea eliminar el régimen RUS, ¿qué motiva tal posición? Obtenido de sitio Web del Diario Gestión: https://gestion.pe/economia/sunat-plantea-eliminar-regimen-rusmotiva-posicion-144042 
Solórzano Tapia, D. L. (2011). Estudios de opinión pública de la actitud de los contribuyentes y demás usuarios ante los sistemas y administraciones tributarias: metodologías, experiencias y tendencias. Centro Interamericano de Administraciones Tributarias.

Superintendencia Nacional de Aduanas y de Administración Tributaria (SUNAT). (18 de Enero de 2017). Promueve su formalización: Nuevo Régimen MYPE Tributario reduce costos de Cumplimiento de Pequeños Negocios. Lima. Obtenido de sitio Web de la SUNAT: http://www.sunat.gob.pe/salaprensa/2017/enero/NotaPrensaN0102017.doc

Superintendencia Nacional de Aduanas y de Administración Tributaria (SUNAT). (s.f.). Definición de la Micro y Pequeña Empresa. Obtenido de sitio Web de la SUNAT: http://www.sunat.gob.pe/orientacion/mypes/define-microPequenaEmpresa.html

Tribunal Constitucional. (19 de Diciembre de 2003). STC 2727-2002-AA/TC. Obtenido de http://www.tc.gob.pe/jurisprudencia/2004/02727-2002-AA.pdf

Tribunal Constitucional. (21 de Setiembre de 2004). STC 0004-2004-AI/TC. Obtenido de https://tc.gob.pe/jurisprudencia/2004/00004-2004-AI\%20Admisibilidad.html

Tribunal Constitucional. (13 de Abril de 2005). STC 0042-2004-AI/TC. Obtenido de https://tc.gob.pe/jurisprudencia/2005/00042-2004-AI.pdf

Tribunal Constitucional. (29 de Agosto de 2007). STC 00009-2007-PI/TC - 00010-2007PI/TC. Obtenido de https://www.tc.gob.pe/jurisprudencia/2007/00009-2007AI\%2000010-2007-AI.html

Tribunal Constitucional. (28 de Enero de 2014). STC 01902-2013-AA/TC. Obtenido de https://www.tc.gob.pe/jurisprudencia/2014/01902-2013-AA.html

Vidal Cárdenas, E. (17 de Diciembre de 1996). La certeza tributaria y el contribuyente. Recuperado el 22 de Mayo de 2019, de sitio Web de Instituto Peruano de Derecho Tributario: http://www.ipdt.org/uploads/docs/02_Rev46_EVC.pdf

Vidal Henderson, A. (Octubre de 1998). Relación de los Principios Constitucionales Tributarios con el tratamiento conferido por El Impuesto al Patrimonio Neto Personal a los Sujetos No Domiciliados en el Perú, 17. Recuperado el 22 de Mayo de 2019, de sitio Web de Instituto Peruano de Derecho Tributario: http://www.ipdt.org/uploads/docs/22_Rev17_AVH.pdf 
Zavalla, C. (2003). Impuestos y Equidad: A propósito de las últimas medidas tributarias. En DESCO, Peru Hoy; la economía bajo presión de la democracia (Primera ed., pág. 275). Lima: Centro de Estudios y Promoción del Desarrollo. Obtenido de http://www.desco.org.pe/la-economia-bajo-presion-de-la-democracia-serieperu-hoy-n\%C2\%BA-3-julio-2003 


\section{BIBLIOGRAFÍA}

Reformas sobre simplificación administrativa en aduanas y tributos. (2013). Lima: SUNAT, INDESTA.

Gómez Sabaíni y Morán (2012). Informalidad y tributación en América Latina: Explorando los nexos para mejorar la equidad. Santiago: CEPAL.

Alonso, G. L. M. (2008). La tributación de la renta empresarial: Derecho comparado. Madrid [etc.: Marcial Pons.

Barragán A., P. (2005). Magnitud de la economía informal en el Perú y el mundo. En: Gestión en el Tercer Milenio, Revista de Investigación de la Facultada de Ciencias Administrativas, UNMSM, Vol. 7, No 14, Lima, noviembre 2005. Obtenido de: http://sisbib.unmsm.edu.pe/BibVirtualData/publicaciones/administracion/N14_2 005/a04.pdf. 